Volume 117

Issue 1 Dickinson Law Review - Volume 117,

2012-2013

6-1-2012

\title{
Administrative Patent Levers
}

David Orozco

Follow this and additional works at: https://ideas.dickinsonlaw.psu.edu/dlra

\section{Recommended Citation}

David Orozco, Administrative Patent Levers, 117 Dick. L. REV. 1 (2012).

Available at: https://ideas.dickinsonlaw.psu.edu/dlra/vol117/iss1/2

This Article is brought to you for free and open access by the Law Reviews at Dickinson Law IDEAS. It has been accepted for inclusion in Dickinson Law Review by an authorized editor of Dickinson Law IDEAS. For more information, please contactlja10@psu.edu. 


\title{
Articles
}

\section{Administrative Patent Levers}

\section{David Orozco*}

\begin{abstract}
This article describes the processes involving the U.S. Patent and Trademark Office's (PTO's) implementation of administrative patent levers related to business methods. Administrative patent levers are conceptualized in this article as rules that represent a coordinated policy at the PTO to target a particular technology class, are often motivated by signals sent by actors within all three branches of government, and can be explained by positive political theory. This article presents an account where policymakers in all branches of government reacted strongly to the dangers posed by business method patents. The PTO's behavior is explained under the "fire-alarm" theory of regulatory change, whereby an administrative agency responds to external institutional pressures and actors. This conceptual analysis of administrative patent levers is then
\end{abstract}

* Assistant Professor of Legal Studies, The College of Business, Florida State University, dorozco@fsu.edu. The author appreciates the comments received from Professors Dan Cahoy, Jake Linford, David Markell, Mark Seidenfeld, David Zaring, the editorial staff at the Penn State Law Review, and from the participants at the 2011 Academy of Legal Studies in Business Conference. The author acknowledges the helpful assistance of Adam Brown. Any errors are solely the author's responsibility. An earlier version of this article was nominated to receive the Holmes-Cardozo research award at the 2011 Academy of Legal Studies in Business Conference. 
informed by a detailed analysis of business method rules that fall under this category of administrative policymaking at the PTO.

A descriptive account is then offered that predicts how the U.S. Court of Appeals for the Federal Circuit (CAFC) would review the PTO's use of administrative patent levers. Ultimately, the CAFC's likely approach is undesirable because it fails to recognize that the PTO engages in policymaking. A normative solution is offered whereby the reviewing courts would apply a "hard look" review under Section 706(2)(A) of the Administrative Procedure Act. This standard would require that the $\mathrm{PTO}$ offer objective evidence that any administrative patent levers are warranted. This standard would also require that the PTO address any valid arguments or evidence against the implementation of such technology-specific and policy-oriented rules. Under this line of analysis, it is proposed that current business method administrative patent levers would fail to meet this standard of review.

\section{Table of Contents}

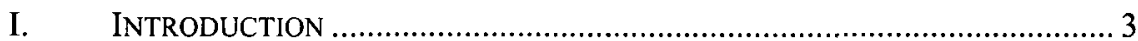

II. BUSINESS METHOD PATENTS ............................................................. 8

III. THE SOCIAL COST OF BUSINESS METHOD PATENTS ............................. 14

A. Patenting Overly Broad Claims ................................................ 15

B. Using Business Method Patents to Extract Unfair Settlements...... 17

IV. INSTITUTIONAL REACTIONS TO BUSINESS METHODS ACROSS THE THREE BRANCHES OF GOVERNMENT ................................................... 19

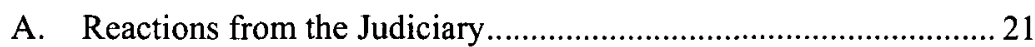

B. Reactions from the Legislature ........................................... 22

C. Reactions from the Executive Branch .......................................... 27

V. THE PTO's RESPONSE to Business Method Fire Alarms:

ADMINISTRATIVE PATENT LEVERS ..................................................... 30

A. Examination Procedures .............................................................. 32

1. New Expert Examiner Category ............................................ 32

2. Mandatory Field Searching .............................................. 32

3. "Second Pair of Eyes" Review................................................ 33

B. Partnerships with External Parties ............................................... 33

1. Coordination with External Parties to Improve Search

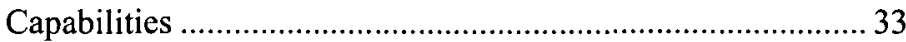

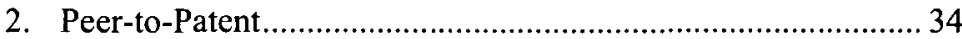

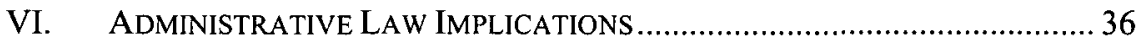

A. General Administrative Patent Law Framework........................... 37

B. The CAFC's Framework for Assessing the PTO's Administrative Patent Levers......................................................... 38

1. Analysis of PTO Rules that Reflect Factual Findings.............. 39

2. Analysis of PTO Rules Having Legal Effect ..........................40 


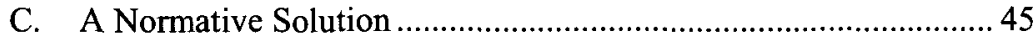

VII. CONCLUSION

\section{INTRODUCTION}

The press has cited examples of questionable patents including those for peanut butter and jelly sandwiches, golf swings, and gene-related inventions. Certainly, Congress should not legislate in a way that throws the baby out with the bath water. I am pleased to hear about all the developments . . including the steps that the [U.S. Patent and Trademark Office] has taken to tighten its review process to improve the examination of these applications and thus increase the quality of issued patents, especially in the area of business patents.

In 2011 , patent reform took the center stage of national policy debates. $^{2}$ On March 8th of that year, the U.S. Congress passed The America Invents Act, a comprehensive bill to reform The Patent Act of 1952 (the "Patent Act"), and President Obama signed the legislation into law on September 16, 2011. ${ }^{3}$ This legislative overhaul has been described as the most significant patent reform achieved in 60 years. ${ }^{4}$ In prior years, the legislature introduced bills that would have transformed

1. Business Method Patents: Hearing Before the Subcomm. on Courts, the Internet, and Intellectual Prop., Comm. on the Judiciary, 107th Cong. (2001) (opening statement of Rep. Howard Coble, Chairman, Subcomm. on Intellectual Prop., Competition, \& the Internet, Comm. on the Judiciary).

2. See, e.g., Edward Wyatt, Senators to Debate Patent Bill, N.Y. TIMEs, Feb. 27, 2011 , available at $\mathrm{http}: / /$ nyti.ms/gTTBKK.

3. The Senate enacted the America Invents Act, S. 23, 112th Cong. (2011) (enacted), by a vote of 95 to 5 . The House likewise passed a similar version, the LeahySmith America Invents Act. See H.R. 1249, 112th Cong. (2011). Among the important changes to patent law made by the America Invents Act is a first-to-file system, broader ability for third parties to challenge issued patents, a provision to eliminate certain business method tax patents, and the ending of "fee diversion" so that the PTO may keep the fees it collects from operations.

4. Press Release, Sen. Chris Coons, Statement on Successful Cloture Vote on the America Invents Act (Mar. 7, 2011), available at http://bit.ly/NsKGm9. 
patent law. ${ }^{5}$ These various bills, however, consistently failed due to the conflicting patent goals held by various industry constituents. ${ }^{6}$

As will be demonstrated in this article, the complex dynamics of patent reform extend far beyond the legislature enacting statutory changes. The judiciary, for example, stepped in recently to fill the void created by legislative inertia and modified various substantive aspects of patent law. ${ }^{7}$ There is an additional element of patent reform, however,

5. There have been multiple instances where the legislature tried but failed to institute patent reforms. See Patent Reform Act of 2007, S. 1145, H.R. 1908, 110th Cong. (2007) (among this Act's major provisions were: first-to-file rights; provisions to facilitate filing a patent application without inventor cooperation; limitation of damages to the economic value of the improvement; limitations on when damages may be trebled for willfulness; post-grant opposition proceedings and venue limitations); Carl E. Gulbrandsen et al., Patent Reform Should Not Leave Innovation Behind, 8 J. MARSHALL REV. INTELL. PROP. L. 328 (2009) (describing the many patent-related congressional bills that have been proposed in the past).

6. See David Orozco \& James G. Conley, Friends of the Court: Using Amicus Briefs to Identify Corporate Advocacy Positions in Supreme Court Patent Litigation, 2011 U. ILL. J.L. TECH. \& POL'Y 107 (2011) (discussing how corporations with differing attributes, such as size and patent capabilities, advocate for different patent law outcomes). This gridlock scenario was recently portrayed in the following manner by one legislator:

Whatever the fate of patent reform in the coming weeks, we can all agree that Congress has found it difficult to enact a truly comprehensive reform bill. Why? The answer is twofold. First, different versions of the legislation have addressed many core provisions of the Patent Act. And second, a number of different stakeholders use the patent system in different ways. Businesses that devote significant resources on research and development have a greater financial need for patent protection than those spending less on R\&D. In addition, some companies may generate one or two clearly understood patents that define an entire product while others, in the software or tech realms, may develop products that contain hundreds or even thousands of patents. In addition, many industries practice their patent portfolio defensively while other industries and patent-holding companies tend to go on the offensive to pursue their patent rights.

Review of Recent Judicial Decisions on Patent Law: Hearing Before the Subcomm. on Intellectual Prop., Competition, \& the Internet of the H. Comm. on the Judiciary, 112th Cong. 1 (2011) (statement of Rep. Bob Goodlatte, Chairman, Subcomm. on Intellectual Prop., Competition, \& the Internet).

7. See, e.g., Microsoft v. i4i Ltd. P'ship, 131 S. Ct. 2238 (2011) (holding that patents are presumed valid and that a claim of invalidity must be proven under a clear and convincing standard of proof); In re Seagate Technology, 497 F.3d 1360 (Fed. Cir. 2007) (increasing the standard of proof necessary to establish willful infringement); eBay v. MercExchange, L.L.C., 547 U.S. 388 (2006) (requiring patentees to comply with the equitable factor test to obtain a permanent patent injunction); Bilski v. Kappos, $130 \mathrm{~S}$. Ct. 3218 (2010) (holding that business methods are patentable); KSR Int'l Co. v. Teleflex Inc., 550 U.S. 398 (2007) (adjusting the obviousness standard). Since Congress had failed to institute general patent reform, some scholars argued that the courts were the last viable option to substantially re-tailor the patent laws in light of the advancing technological changes in the economy, which arguably require a more flexible, principles-based approach to patent doctrine. Professors Dan Burk and Mark Lemley, in particular, advanced the idea that the courts should employ judicial patent levers to make 
that remains vastly underappreciated and which operates largely hidden beneath the surface. This largely unnoticed aspect of patent reform deals with the administrative rules created by the U.S. Patent and Trademark Office (PTO).

This article examines several administrative rules that the PTO implemented to effectively manage a controversial category of patent applications known as business methods. These rules, labeled "administrative patent levers," technology-specific and guided primarily by policy motivations and institutional signals initiated by actors within all three branches of government. This article also examines the legality of administrative patent levers under established administrative law doctrine and proposes a solution to the current flawed regime.

In particular, this article addresses how the PTO enacted a complementary set of norms and rules to restrict business method patents, which are viewed as a particularly suspect category of patents. ${ }^{9}$ This article also maintains that the adoption of administrative patent levers at the PTO corresponds with the judicial, legislative, and executive branches' coordinated apprehension towards business method patents. The PTO's use of administrative patent levers, for example, went hand in hand with the Supreme Court's patent law clarifications achieved through the use of complementary judicial patent levers. ${ }^{10}$ There remained significant room, however, for the PTO to fill in any policy vacuums that lingered via its administrative rulemaking function." In the context of business methods, administrative patent levers were

patent law adjustments that reflect the plurality of participants and industry conditions. See Dan L. Burk \& Mark A. Lemley, Policy Levers in Patent Law, 89 VA. L. REV. 1575 (2003).

8. This labeling borrows from Professor Dan Burk and Mark Lemley's analogous conception of judicial patent levers. See Burk \& Lemley, supra note 7 (describing how courts can tailor patent law doctrine to reach suitable outcomes depending on the industrial context). Like the judicial patent levers conceptualized by professors Burk and Lemley, administrative patent levers are policy-oriented and technology-specific.

9. See eBay, 547 U.S. at 397.

10. Burk \& Lemley, supra note 7.

11. See Cornelius M. Kerwin, Rulemaking: How Government Agencies Write LAW AND MAKE POLICY 6 (1st ed. 1994) (discussing how administrative agencies engage in rulemaking to fill policy or legal vacuums under the Administrative Procedure Act, and that when the demands on these administrative institutions increase, the more likely administrative rulemaking expands); $c f$. Mark A. Lemley, Rational Ignorance at the Patent Office, 95 Nw. U.L. REv. 1495 (2001) (discussing that the PTO is rationally ignorant of low quality patents because the cost of acquiring information to reach a high quality patentability judgment exceeds the social benefit, given that most patents are never legally asserted). Professor Lemley recommends that enacting general rules to improve patent quality would be socially inefficient and that the courts present a better forum for resolving patent quality issues. $I d$. 
developed to address some of the very real challenges associated with these types of patents. ${ }^{12}$ As will be discussed below, however, the use of administrative patent levers comes with some significant risks. The levers, for example, may raise the cost and burden of compliance among patent applicants in a way that does not comport with a principled legal standard.

For example, one of Facebook Inc.'s patent applications relates to a computer implemented method of selecting terms discussed by social media users and associating those terms with topics, frequency ranks, and users' demographic characteristics. ${ }^{13}$ Although this application arguably involves a business method, it was classified as a database technology. ${ }^{14}$ Had the application been classified as a business method, the administrative patent levers discussed below would have triggered a substantially more rigorous and onerous level of review at the PTO. As will be discussed, such an unprincipled application of administrative patent levers may be challenged as arbitrary or capricious under administrative law doctrine.

Although a great deal of attention has been devoted to why certain policies and rule-making practices at the PTO are either desirable or undesirable, ${ }^{15}$ little attention has been devoted to examine how these rules and policies are instituted and legitimized. This discrepancy has resulted in a scenario where PTO rulemaking all too often resembles a "black box" to external observers. The process through which administrative patent levers emerge has received scant consideration among scholars and practitioners. The portrait provided in this article challenges the widely held notion that the PTO primarily enacts rules that mechanically execute the legal norms distilled from the Patent Act and the binding judicial interpretations of that statute. Instead, this article posits that the PTO has increased its role as a substantive policymaker in the area of patent law through its creation of administrative patent levers, and that it will likely continue down this path in the foreseeable future. ${ }^{16}$ However, this path poses a significant

12. See discussion infra Part III (describing the unique challenges raised by business method patents).

13. U.S. Patent Application No. 20100169327 (filed Dec. 31, 2008).

14. Id. The application was classified under technology Class 707 , which pertains to database technologies. See U.S. PATENT \& Trademark OfFicE, USPTO Class SCHEDULE, http://1.usa.gov/OzlUml (last visited July 20, 2012).

15. See Arti Rai, Growing Pains in the Administrative State: The Patent Office's Troubled Quest for Managerial Control, 157 U. PA. L. REV. 2051, 2051-81 (2009).

16. See Sarah Tran, Patent Powers, 25 HARV. J.L. \& TECH. 595, 599 (2012) (stating that the America Invents Act "continues the trend since 1999 of shifting control and influence over patent law from the courts to the USPTO"); Clarissa Long, The PTO and the Market for Influence in Patent Law, 157 U. PA. L. REV. 1965, 1966 (2009) (describing how the PTO has maneuvered since the early 1990s to gain more influence 
challenge because the PTO, unlike most administrative agencies, lacks substantive rule-making authority, and its foray into substantive rulemaking will likely be reviewed by the federal courts.

The implementation of business method administrative patent levers is explained through the lens of positive political theory. Positive political theory examines the influence that political bodies and institutions have on legal doctrine and legal outcomes. ${ }^{17}$ From this perspective, the political institutions that influenced the creation of administrative patent levers at the PTO include governmental advocacy manifested on the record in legislative bills, roundtable discussions, hearings, and official policy statements. As proposed in this article, the treatment extended to business methods across all branches of government helps to explain why the PTO adopted extraordinary business method patent norms and rule-making to a degree not seen outside of other controversial patent areas such as software, biotechnology, or green technology. ${ }^{18}$ This behavior, although descriptively accounted for by positive political theory, is not devoid of potentially harmful, unintended consequences, as will be further elaborated below. ${ }^{19}$

The article will proceed with Part II introducing the context, history, and conceptual contours of business method patents. Part III will survey the academic literature to expose the unique dangers imposed by these patents on innovators and society. Part IV will examine how the judicial, legislative, and executive branches all reacted to the vocal warnings of these dangers. Part V will analyze the PTO's reaction to these institutional and public policy reactions. This Part will also discuss five administrative business method patent levers that the PTO developed in response to the widespread institutional pressure, and the effect that these

and occupy a more central position in making patent law and policy). The America Invents Act likewise calls for greater PTO policymaking since the law includes a section enabling the PTO to provide priority examination for technologies that are important to American competitiveness. Pub. L. No. 112-29, § 26, 125 Stat. 284 (2011). See Dan Cahoy, Inverse Enclosure: Abdicating the Green Technology Landscape 22 (2012) (unpublished manuscript) (on file with the author). Determining what technologies are important to American competitiveness will be within the PTO's policymaking discretion.

17. See Daniel B. Rodriguez, The Positive Political Dimensions of Regulatory Reform, 72 WASH. U. L.Q. 1, 43 (1994) ("[P]ositive political theory describes regulatory policymaking as a part of a world in which political actors function within institutions rationally and strategically to accomplish certain goals"). See generally DougLASS C. North, Institutions, Institutional Change and ECONOMIC PeRformanCE (1990).

18. See David Orozco, Administrative Patent Levers in the Software, Biotechnology and Clean Technology Industries (2012) (unpublished manuscript) (on file with the author).

19. See discussion infra Part VI.C (describing several risks involving the use of administrative patent levers). 
measures have had on business method patenting. Finally, Part VI will discuss the administrative law implications raised by the PTO's use of the levers, their questionable legality and broader policy implications, and a normative solution.

\section{BUSINESS METHOD PATENTS}

Business methods provide a good opportunity to examine administrative patent levers because they raise significant concerns among a broad range of stakeholders. That is not to say that business methods are the only technological area where the PTO has exercised discretion in implementing administrative patent levers. The PTO has, for example, implemented patent levers in other controversial and challenging technology areas such as software, biotechnology, and green technology. ${ }^{20}$ As will be discussed, however, business methods are a subset of patents that have raised an inordinate measure of concern. Before discussing the PTO's use of patent levers to deal with business methods, this part will provide some background information regarding business methods.

Business method patents, like patents in general, can be key economic resources in today's knowledge-based economy. ${ }^{21}$ Companies use legal knowledge and resources to secure an advantage in and property rights to a broad category of innovations, including what appear to be fundamental business techniques. ${ }^{22}$ Take the case of the online retailer Amazon.com, which patented its "one-click" shopping method ${ }^{23}$

20. See Orozco, supra note 18 , at 4-26.

21. One witness before a recent congressional hearing on patents testified:

[I]n 1984, the book value of the 150 largest U.S. companies ... was equal to 75 percent of their market value; that is, large U.S. companies were worth a little more than their physical assets. In 2005, the book value of the 150 largest U.S. Companies was equal to 36 percent of their book value. Two-thirds of the value of large U.S. Corporations in this period are derived from intangible assets and not from their physical assets. That's an idea-based economy.

How an Improved U.S. Patent and Trademark Office Can Create Jobs, Hearing before the Subcomm. on Intellectual Prop., Competition, \& the Internet, 112th Cong. 1 (2011) (statement of Robert J. Shapiro); see also Norman D. Bishara \& David Orozco, Using the Resource-Based Theory to Determine Covenant-not-to-Compete Legitimacy, 87 IND. L.J. 979 (2012) (describing how companies increasingly use non-compete contract terms to obtain competitive advantage in a knowledge-based economy).

22. See David Orozco, Legal Knowledge as an Intellectual Property Management Resource, 47 AM. Bus. L.J. 687, 718-21 (2010) (describing how firms attempt to strategically shape the immediate legal environment through private legal strategies); David Orozco, Rational Design Rights Ignorance, 46 AM. Bus. L.J. 573-605 (2009) (describing how some companies use legal knowledge to integrate intellectual property rights to achieve design-based product differentiation).

23. Amazon's "one-click" patent claimed the idea that a browser-enabled command to buy a certain item online will carry information about the purchaser's identity by sending the server a "cookie," or code that the browser received previously from the 
and later sued competitor Barnes and Noble for patent infringement. ${ }^{24}$ Amazon used the patent on its e-commerce shopping method to obtain an injunction and, eventually, a settlement from Barnes and Noble. In a similar case, Netflix patented its entire business model of renting items to shoppers online. ${ }^{25}$ Netflix eventually used the patent to sue competitor Blockbuster when it offered a competing online movie rental service. That case was also settled, with terms believed to be favorable to Netflix. $^{26}$ In both cases, business method patents were at the heart of fierce competitive battles between emergent online retailers and the dominant brick-and-mortar incumbents. ${ }^{27}$

The legal validity of some business method patent claims, however, remains questionable because some of these claims extend to subject matter that appears to be generally known, or is obvious in light of the prior art. ${ }^{28}$ For example, in the Amazon case mentioned above, Amazon's one-click patent was subsequently re-examined by the U.S. Patent and Trademark Office (PTO). After its re-examination, the PTO rejected claims 1-5 and 11-26 of Amazon's patent as improperly

same server. See Why We Boycott Amazon, FreE SoFTwARE Found., http://bit.ly/auUuQx (last visited Aug. 4, 2012).

24. Amazon.com, Inc. v. Barnesandnoble.com, Inc., 73 F. Supp. 2d 1228 (W.D. Wash. 1999), vacated, 239 F.3d 1343 (Fed. Cir. 2001).

25. U.S. Patent No. 7,024,381 (filed May 14, 2003). Claim 1 of this patent reads: A computer-implemented method for renting movies to customers, the method comprising: providing electronic digital information that causes one or more attributes of movies to be displayed; establishing, in electronic digital form, from electronic digital information received over the Internet, a movie rental queue associated with a customer comprising an ordered list indicating two or more movies for renting to the customer; causing to be delivered to the customer up to a specified number of movies based upon the order of the list; in response to one or more delivery criteria being satisfied, selecting another movie based upon the order of the list and causing the selected movie to be delivered to the customer; and in response to other electronic digital information received from the customer over the Internet, electronically updating the movie rental queue.

26. Blockbuster, Netflix Settle Patent Dispute, REUTERs (June 27, 2007, 10:33 AM), http://reut.rs/kC6914. Arguably, the business outcome was extremely favorable to Netflix, as Blockbuster has since filed for bankruptcy. Id.

27. Other highly visible cases raised an alarm over the breadth of business methods. The popular online auction site Priceline.com, for example, asserted its patent on reverse online auctions. See Priceline.com v. Expedia, No. 99-CV-1991 (D. Conn. Oct. 13, 1999).

28. See Robert P. Merges, As Many as Six Impossible Patents Before Breakfast: Property Rights for Business Concepts and Patent System Reform, 14 BERKELEY TECH. L.J. 577 (1999); Wade M. Chumney, David L. Baumer \& Roby B. Sawyers, Patents Gone Wild: An Ethical Examination and Legal Analysis of Tax-Related and Tax Strategy Patents, 46 AM. BUS. L.J. 343 (2009); Robert E. Thomas, Vanquishing Copyright Pirates and Patent Trolls: The Divergent Evolution of Copyright and Patent Laws, 43 AM. BuS. L.J. 689, 689-739 (2006). 
granted. ${ }^{29}$ According to scholars, a significant portion of business method patent claims are of suspect validity because the examiners at the PTO lacked the experience necessary to properly evaluate many of the claims granted in these patents. ${ }^{30}$ Likewise, a good deal of controversy surrounds business method patents because they may be used to stifle competition in rapidly evolving areas of business, such as e-commerce. Commentators also point out that business method patents may wreak havoc if they fall into the wrong hands. ${ }^{31}$ Several prominent cases are highlighted where patent trolls, also referred to as non-practicing entities (NPEs), aggressively wield business method patents. A NPE's sole objective is to sue large companies and threaten a hold-up by obtaining an injunction. ${ }^{32}$

The trend toward stronger and broader patent rights amplified the effects of business method patents. ${ }^{33}$ This trend was propelled by the creation of the Court of Appeals for the Federal Circuit (CAFC), a special jurisdiction court that decides patent appeals. ${ }^{34}$ To clarify the boundaries of patent rights, the CAFC promulgated formalistic patent jurisprudence that emphasizes clearly defined tests and rules. To some commentators, these tests led to a pro-patentee shift that presented significant risks to firms because patent owners, and particularly patent trolls, were empowered under the rules to hinder innovation via the legal system by engaging in hold-ups and other extortionist tactics. ${ }^{35}$

Another contentious issue concerning business method patents is whether they can be conceptually identified as a unique category of invention. ${ }^{36}$ From a statutory perspective, the U.S. Patent Act initially failed to provide guidance other than suggesting that business methods fell under the allowed general category of "processes," subject to

29. Jacqui Cheng, Amazon's 1-Click Patent Picked Apart by U.S. Patent Office, ARS TECHNICA (Oct. 17, 2007, 1:14 PM), http://bit.ly/JEMagR.

30. See, e.g., Merges, supra note 28.

31. See, e.g., Thomas, supra note 28 , at 721 .

32. Id.

33. See Arti Rai, Addressing the Patent Gold Rush: The Role of Deference to PTO Patent Denials, 2 WASH. U. J.L. \& POL'Y 199, 202-12 (2000) (discussing how the CAFC's reversal of the PTO's denial of biotechnology and computer-related patents led to a sharp rise in patent filings in these technology areas).

34. See Samuel Kortum \& Josh Lerner, Stronger Protection or Technological Revolution: What Is Behind the Recent Surge in Patenting?, 48 CARNEGIE-ROCHESTER CONFERENCE SERIES ON PUB. POL'y 247(1998).

35. See Mark A. Lemley \& Carl Shapiro, Frontiers of Intellectual Property: Patent Holdup and Royalty Stacking, 85 TEX. L. REV. 1991 (2007).

36. John R. Allison \& Starling D. Hunter, On the Feasibility of Improving Patent Quality One Technology at a Time: The Case of Business Methods, 21 BERKELEY TECH. L.J. 729, 765 (2006) ("All attempts by courts and Congress to arrive at a workable definition for business methods have encountered intractable difficulties."). 
general, well established exceptions. ${ }^{37}$ In response to the perceived dangers of business methods, The Patent Act was later amended to provide a prior use defense related to methods of "doing or conducting business." This amendment, however, failed to clearly define the term method of "doing or conducting business." 38

In 2001, Congress introduced a bill, The Business Method Patent Improvement Act, which would have raised the obviousness standard for business methods. ${ }^{39}$ This bill actually defined business methods as

(1) a method of processing data; or performing calculation operations; and which is uniquely designed for or utilized in the practice, administration, or management of an enterprise;

(2) any technique used in athletics, instruction, or personal skills; and

(3) any computer-assisted implementation of a method described in paragraph (1) or a technique described in paragraph (2). . .40

The bill was never enacted, however, so the definition lacks any statutory authority.

The judiciary has referred to business methods without precisely articulating the contours of this technology class. The earliest case cited for the proposition that business methods remained beyond patentability is Hotel Security Checking Co. v. Lorraine Co. ${ }^{41}$ In that case, the U.S. Court of Appeals for the Second Circuit held that patent claims for a bookkeeping system were unpatentable per se. A series of subsequent cases reinforced the presumption that a "business method exception" excluded business methods from being patentable. ${ }^{42}$ The advent of information and communications technology, however, challenged the per se rule against patents covering data processing. ${ }^{43}$ In 1981 , the U.S.

37. 35 U.S.C. $\S 101$ (2006). The well-established exceptions to patentability developed by the U.S. Supreme Court are laws of nature, physical phenomena, and abstract ideas. See Diamond v. Chakrabarty, 447 U.S. 303, 309 (1980).

38. Allison \& Hunter, supra note 36 , at 766.

39. H.R. 1332, 107th Cong. (2001).

40. Id. $\S 2(\mathrm{f})$.

41. Hotel Security Checking Co. v. Lorraine Co, 160 F. 467 (2d Cir. 1908); Thomas R. Makin, Hotel Checking: You Can Check Out Any Time You Want, But Can You Ever Leave? The Patenting of Business Methods, 24 Colum.-VLA J. L. \& ARTS 93, 94 (2000); Russell A. Korn, Is Legislation the Answer: An Analysis of the Proposed Legislation for Business Method Patents, 29 FLA. ST. U. L. REV. 1367, 1369 (2002).

42. See, e.g., Parker v. Flook, 437 U.S. 584 (1978) (holding that mathematical algorithms are not patentable).

43. See Gottschalk v. Benson, 409 U.S. 63 (1972). In this case, the Supreme Court rejected a patent on a computerized method for converting decimal numbers to binary 
Supreme Court relaxed its rule against software patents in Diamond $v$. Diehr. ${ }^{44}$ In that case, the Court held that a software algorithm might be patentable as a process if it claims a "useful, concrete and tangible result." $" 45$

The legal status of business methods, as opposed to software algorithms, was later settled when the CAFC decided the State Street case ${ }^{46}$ In that case, the CAFC dismissed the business method exception altogether, holding that a software algorithm for processing data in a system was patentable. Following the Supreme Court's reasoning, the CAFC found the algorithm created a "useful, concrete and tangible result" that may be patentable even if the result is something as nonphysical as an investment value. ${ }^{47}$ Ultimately, the CAFC mentioned that the business method exception was incompatible with the Supreme Court's interpretation of the Patent Act, and that any rejections of business methods in the past had been based on statutory issues such as novelty, not on a per se categorization and exclusion of business methods. ${ }^{48}$

State Street raises the issue of whether the definition of a business method patent can ever be grounded in principle. ${ }^{49}$ Some commentators argue that business methods precede the modern understanding of these processes because inventors have patented methods that have pertained to business processes as far back as $1889 .{ }^{50}$ Other commentators point out that the claims need not even be drafted as methods and that, despite any regulation, patent drafters routinely construct claims that reflect business methods as elements of a machine or system. ${ }^{51}$

numbers because the patent applied an abstract scientific or mathematical principle. $I d$. at 73 .

44. Diamond v. Diehr, 450 U.S. 175 (1981).

45. Id. (holding, however, that purely abstract ideas remain beyond patentability); see also Arrhythmia Research Technology, Inc. v. Corazonix Corp., 958 F.2d 1053, 1061 (Fed. Cir. 1992) (holding that a mathematical process for detecting and analyzing electrocardiographic signals are patentable).

46. State St. Bank \& Trust Co. v. Signature Financial Fin. Grp., 149 F.3d 1368 (Fed. Cir. 1998), cert denied, 525 U.S. 1093 (1999).

47. State St. Bank \& Trust Co., 149 F.3d at 1375.

48. Id.

49. See John R. Allison \& Emerson Tiller, The Business Patent Myth, 18 BERKELEY TECH. L.J. 987 (2003).

50. U.S. Patent \& Trademark Office, White Paper on Automated Financial Or Management Data Processing Methods (Business Methods) (White Paper Ver. 1.43) [hereinafter PTO WHITE PAPER] ("On January 8, 1889, the era of automated financial/management business data processing method patents was born. United States patents 395,$781 ; 395,782$; and 395,783 were granted to inventor-entrepreneur Herman Hollerith on that date."), available at http://bit.ly/Mpn5ZC.

51. Merges, supra note 28. 
Recently, the Supreme Court addressed the question of what test should determine the patentability of business methods. ${ }^{52}$ In that case, the Court rejected the CAFC's exclusive use of the "machine or transformation test" to determine business method patentability and, in the process, the Court commented on the broader question of whether business methods are even patentable. ${ }^{53}$ The Court stated:

Section 101 similarly precludes the broad contention that the term "process" categorically excludes business methods. The term "method," which is within $\S 100(b)$ )'s definition of "process," at least as a textual matter and before consulting other limitations in the Patent Act and this Court's precedents, may include at least some methods of doing business. ${ }^{54}$

However, the Bilski Court, like other courts, did not define business method patents. The case has been criticized for failing provide a clear standard to determine business method patentability. According to some scholars, the Bilski decision leaves a considerable leeway for lower courts to apply discretion. ${ }^{55}$ This leeway similarly applies to the PTO and increases the role for administrative patent levers as substantive policy instruments in this technology area.

The PTO offers a working definition of business methods. The PTO identifies business method patents primarily, though not exclusively, through technology Class 705: "Data Processing, Financial, Business Practice, Management, or Cost/Price Determination." According to the PTO, Class 705

is the generic class for apparatus and corresponding methods for performing data processing operations, in which there is a significant change in the data or for performing calculation operations wherein the apparatus or method is uniquely designed for or utilized in the practice, administration, or management of an enterprise, or in the processing of financial data. ${ }^{56}$

52. Bilski v. Kappos, 130 S. Ct. 3218 (2010).

53. Id.

54. Id.

55. Susan J. Marsnik \& Robert E. Thomas, Drawing a Line in the Patent SubjectMatter Sands: Does Europe Provide a Solution to the Software and Business Method Patent Problem?, 34 B.C. INT'L \& COMP. L. REv. 227, 264 (2011). The CAFC recently provided guidance regarding software patentability in light of the Bilski decision. See Research Corp. Techs. v. Microsoft Corp., 627 F.3d 859 (Fed. Cir. 2010) (upholding the validity of software method claims and ruling that the claims were not abstract in light of the Bilski decision).

56. Class Definition, Class 705, U.S. Patent \& Trademark OfFice, http://1.usa.gov/QmhWmj (last visited Aug. 4, 2012). The PTO definition of business methods matches a business method definition offered by Professor Daniel Spulber. Business method patents are defined by Professor Spulber as "the discovery of a 
Given the likely insurmountable lack of definitional precision, it is unsurprising that business method patents have been asserted in a variety of cases involving financial products, ${ }^{57}$ insurance products, ${ }^{58}$ tax methods, ${ }^{59}$ and e-commerce. ${ }^{60}$ It is not coincidental, however, that business method patents became a salient issue as online business transactions proliferated. The rapid emergence of online business transactions amplified the market power of business method patent owners who increasingly and aggressively asserted methods related to electronic means of conducting business. The State Street decision opened "the floodgates" to business method patenting and litigation. ${ }^{61}$ One source reports that, in the year before the State Street case was decided, the PTO received 1,300 business method applications. ${ }^{62}$ In following year, the PTO received 7,800 business method applications. ${ }^{63}$

\section{The Social Cost OF Business Method PATENTS}

Administrative patent levers are implemented to deal with the negative effects of certain technologies. As certain technologies become increasingly cumulative ${ }^{64}$ and distributed, ${ }^{65}$ patents raise considerable transaction costs if they are used to block technological progress or implementation. ${ }^{66}$ As recognized in the literature, there are several

commercial technique for firms to address market opportunities, such as a transaction procedure, market microstructure, financial system, operational process, or organizational form." Daniel F. Spulber, Should Business Method Inventions be Patentable?, 3 J. OF LEGAL ANALYSIS 265, 270 (2011).

57. See, e.g., U.S. Patent No. 6,088,685 (filed Aug. 27, 1998).

58. See, e.g., U.S. Patent No. 7,089,201 (filed Sept. 24, 1999).

59. See, e.g., U.S. Patent No. 6,567,790 (filed Dec. 1, 1999).

60. See, e.g., U.S. Patent No. 5,960,411 (filed Sept. 12, 1997).

61. Korn, supra note 41, at 1370; Rai, supra note 33, at 211; Allison \& Hunter, supra note 36 , at $730-31$.

62. Korn, supra note 41 , at 1370-71.

63. Id.

64. Cumulative industries include information and technology communications, semiconductors, biotechnology, and software. Proponents of open software are particularly critical of Internet-related business methods because these patents may block open access to software and technology. See Lawrence Lessig, Patent Problems, THE INDUSTRY STANDARD (Jan. 21, 2000, 12:00 AM), http://bit.ly/MkyHae.

65. Henry Chesbrough, Open Business Models xiii (2006) (discussing how open innovation "means that companies should make greater use of external ideas and technologies in their own business, while letting their unused ideas be used by other companies").

66. See generally James Bessen \& Michael J. Meurer, Patent Failure: How JudGes, BUREAUCRATS, AND LAWYERS PUt INNOVATORS AT RISK 9 (2008) (arguing that vague patent claims in the high tech sector raise costs for the majority of firms); Michael A. Heller \& Rebecca S. Eisenberg, Can Patents Deter Innovation? The Anticommons in Biomedical Research, 280 SCIENCE 698, 698 (1998). Patents of poor quality also raise transaction costs overall, as parties wastefully litigate and duplicate the PTO's efforts to determine patent validity. See John R. Thomas, The Responsibility of the Rulemaker: 
tactics employed by patent owners that disadvantage competitors and impose social costs in the process. ${ }^{67}$ For example, a company can patent a rival substituting technology to prevent others from practicing the invention. ${ }^{68}$ Thus, a superior and socially beneficial alternate technology might never be applied due to these blocking patents. ${ }^{69}$ A patentee may also engage in "evergreening," or patenting an incremental aspect of a preexisting technology to unduly extend the monopoly lifetime of the underlying technology. ${ }^{70}$ Another tactic patentees employ is to engage in strategic filing practices such as abusing the continuation procedure. ${ }^{71}$ Lastly, patent owners may forum shop by filing patent lawsuits in any of the pro-plaintiff "rocket docket" jurisdictions." Two additional strategies are particularly relevant to business method patents and impose social costs when undertaken. These two strategies, which may have prompted the use of administrative patent levers, include patenting overly broad claims and using a patent to extract an unfair settlement.

\section{A. Patenting Overly Broad Claims}

Business method patents are often criticized for being unduly broad. There are a few things to consider regarding this criticism. First, a patent is unduly broad if it improperly claims technology that was disclosed, practiced in the prior art, or was obvious to one with ordinary skill in the art. $^{73}$ Business methods are often criticized as unduly appropriating technology that had been previously practiced or as lacking innovative merit. This criticism has some support because some business methodrelated prior art remained hidden from PTO examiners. ${ }^{74}$

Comparative Approaches to Patent Administration Reform, 17 BERKELEY TECH. L.J. 727, 731 (2002).

67. These tactics, employed by patent owners, go beyond the traditional tactic of asserting a patent to gain exclusivity.

68. Richard J. Gilbert \& David M.G. Newbery, Preemptive Patenting and the Persistence of Monopoly, 72 AM. ECON. REV. 514, 524-25 (1982).

69. Id.

70. See Christine S. Paine, Brand Name Drug Manufacturers Risk Antitrust Violations By Slowing Generic Production Through Patent Layering, 33 SETON HALL L. REv. 479, 497-506 (2003).

71. See Mark A. Lemley \& Kimberly A. Moore, Ending Abuse of Patent Continuations, 84 B.U. L. REV. 63, $71-83$ (2004) (discussing the problems created by the continuation practice).

72. See Medlmmune, Inc. v. Genentech, Inc., 549 U.S. 118 (2007).

73. See 35 U.S.C. $\$ 102(2006)$ (describing the various instances involving prior art that negate novelty in a patent application); 35 U.S.C. $\S 103$ (2006 \& Supp. 2011) (stating that a patent may not be obtained if "the differences between the subject matter sought to be patented and the prior art are such that the subject matter as a whole would have been obvious at the time the invention was made to a person having ordinary skill in the art to which said subject matter pertains").

74. Allison \& Tiller, supra note 49. 
For example, in the case of American Stock Exchange, LLC v. Mopex, Inc. ${ }^{75}$ a non-practicing entity sued the American Stock Exchange (AMEX) for infringing a business method patent related to a financial product known as an exchange-traded fund (ETF). ${ }^{76}$ The PTO granted Mopex a patent to this financial method on July $11,2000 .^{77}$ The AMEX sued to invalidate the patent on the ground that the financial method had been practiced and disclosed in prior art that PTO examiners failed to review. At trial, the AMEX submitted evidence that this type of ETF had been developed, traded, and disclosed by the investment bank Morgan Stanley. ${ }^{78}$ The court considered evidence that, in 1994, Morgan Stanley had submitted a publicly available application for an ETF with the Securities and Exchange Commission. This prior art was then used to invalidate Mopex's business method patent. ${ }^{79}$

A separate but common attack on these patents is that patent examiners handling these applications did not have sufficient training in the emergent fields of Internet commerce, a field with increasingly claimed business methods. A closely related argument is that examiners did not have sufficiently updated non-patent literature databases with industry-relevant prior art that would enable the examiner to narrow or reject unduly broad business method patent claims. ${ }^{80}$ Patent examiners are also notoriously pressed for time due to their increasing workload. ${ }^{81}$ 2002)

75. American Stock Exch., LLC v. Mopex, Inc., 250 F. Supp. 2d 323 (S.D.N.Y.

76. Id. at 325 .

77. Open End Mut. Fund Securitization Process, U.S. Patent No. 6,088,685 (filed Aug. 27, 1998).

78. American Stock Exch., 250 F. Supp. 2d at 326.

79. Id. at 333 .

80. Allison \& Tiller, supra note 49. Sources of non-patent literature include items such as trade press articles, conference materials, technical papers, and doctoral theses.

81. The PTO has described its workload crisis in the following manner:

Today, the United States Patent and Trademark Office (PTO) is under siege. Patent application filings have increased dramatically throughout the world. There are an estimated seven million pending applications in the world's examination pipeline, and the annual workload growth rate in the previous decade was in the range of 20-30 percent. Technology has become increasingly complex, and demands from customers for higher quality products and services have escalated. Our applicants are concerned that the PTO does not have access to all of the fees they pay to have their patent and trademark applications examined, thereby jeopardizing the benefits intellectual property rights bring to our national economy. In the United States, these demands have created a workload crisis.

PTO, The 21st Century Strategic Plan (Feb. 3, 2003), available at http://1.usa.gov/OI3sbi; $c f$. Mark A. Lemley, Rational Ignorance at the Patent Office, 95 Nw. U. L. REV. 1495 (2001) (arguing that devoting resources to strengthen the patent examination process at the PTO would be socially inefficient). 
Accordingly, it is argued that many overly broad business method patent claims have been issued.

\section{B. Using Business Method Patents to Extract Unfair Settlements}

The social costs of overly broad business method patents are amplified when they fall into the hands of the so-called patent trolls, or non-practicing entities (NPEs). ${ }^{82}$ A NPE is a party who owns a patent, does not practice the underlying technology, and uses the patent to sue large companies to obtain a settlement or a verdict. ${ }^{83}$ According to one source, there were more than 2,600 instances in 2010 where a company was the litigation target of a NPE, which represents a 48 percent increase above the average amount of the prior three years. ${ }^{84}$ Other evidence supports this finding. According to the registration statement recently filed with the SEC by a company involved in assembling defensive patent portfolios to protect companies from NPE's, "[T]here were over 550 patent infringement cases filed by NPEs in 2010 against more than 3,000 defendants, which comprised over 2,000 unique companies, some of which were sued more than once." 85

The NPE exploits the fact that it is a small company with no real presence in the market and cannot be counter sued for infringing any of the larger defendant's patents. ${ }^{86}$ Often, when one large company sues another large company (usually a competitor) for patent infringement, the competitor countersues and likewise alleges patent infringement. The result is usually a negotiated cross-license and technology sharing agreement. $^{87}$ A large company does not have this option when it is the target of a patent lawsuit initiated by a NPE.

82. In 2001, Peter Detkin (then assistant general counsel at Intel Corp.) is said to have coined the term "patent troll" to describe firms that acquire patents to extract settlements from companies on dubious infringement claims. See Peter N. Detkin, Leveling the Patent Playing Field, 6 J. MARSHALL REV. INTELL. PROP. L. 636, 636 (2007) (stating that he coined the term).

83. Some commentators suggest that NPEs extract settlements by strategically filing cases against many defendants, and by employing a contingency fee strategy, where the law firm representing the NPE assumes the significant upfront costs of litigation. See Stijepko Tokic, The Role of Consumers in Deterring Settlement Agreements Based on Invalid Patents: The Case of Non-Practicing Entities, 2012 STAN. TeCH. L. REV. 2 (2012).

84. Litigations Over Time, PATENTFREEDOM.COM, http://bit.ly/N1Z8Vm (last visited Aug. 4, 2012).

85. RPX Corp., Registration Statement (Form S-1), at 2 (Jan. 21, 2011), available at http://1.usa.gov/QBVTIA.

86. See NTP, Inc. v. Research in Motion, Ltd., 418 F.3d 1282 (Fed. Cir. 2005).

87. See Peter C. Grindley \& David J. Teece, Managing Intellectual Capital: Licensing and Cross-Licensing in Semiconductors and Electronics, 39 CAL. MGMT. REV. $8,8(1997)$. 
Compounding the problem is that the NPE will often enforce a business method patent against a large company operating in a complex, or cumulative, technology area. ${ }^{88}$ This action places pressure on the defendant because it may be forced to expend considerable resources to design around the patent or may face a complete shutdown if the NPE obtains an injunction. ${ }^{89}$ This action also creates the risk that the NPE will engage in a strategic hold-up ${ }^{90}$ and extort an unreasonably large settlement or verdict. ${ }^{91}$ For example, the NPE Eolas acquired $\$ 521$ million when it obtained a patent injunction against Microsoft. ${ }^{92}$ NTP, Inc., another NPE, notoriously obtained \$612.5 million when it threatened to enforce a permanent patent injunction against Research-InMotion, makers of the "Blackberry" handheld device. 93

Business method patents and their harmful consequences have been uniformly criticized. ${ }^{94}$ However, in one empirical study, Professors Allison and Tiller counter the assertion that business method patents are below average quality. ${ }^{95}$ In their study, Allison and Tiller assess business method patents using well established quality measures and find that no basis exists for claiming that these patents are inferior in terms of the number of prior art references, claims, and inventors. ${ }^{96}$ Professors Allison and Tiller attribute the high levels of public discord regarding business method patents to an information "bandwagon" effect whereby business methods were judged based on the negative comments of experts, with negative views reinforced by a confirmation bias based on public discussions of egregious examples such as Amazon's "one-click" patent. ${ }^{97}$ Allison and Tiller's assessment is supported by the way the

88. See Orozco \& Conley, supra note 6 .

89. Lemley \& Shapiro, supra note 35.

90. Id.

91. See Tokic, supra note 83 , at 10 (stating that, prior to 1990 , there had been only one patent damage award larger than $\$ 100$ million and that, in the last several years, there have been at least 15 judgments and settlements in that category with at least five exceeding $\$ 500$ million).

92. Eolas Techs., Inc. v. Microsoft Corp., 399 F.3d 1325 (Fed. Cir. 2005).

93. This settlement occurred even though the PTO was going to invalidate many of NTP's patent claims. As illustrated by these two cases, it is important to highlight that NPEs may assert patent claims that fall outside the traditional business method patent realm.

94. See Simson L. Garfinkel, Patently Absurd, WIRED, July 1994, http://bit.ly/Mc6XJA; James Gleick, Patently Absurd, N.Y. TyMES, Mar. 12, 2000, http://nyti.ms/QC8HP4; Robert M. Hunt, You Can Patent That?: Are Patents on Computer Programs and Business Methods Good for the New Economy?, 2001 Bus. REV. Q1 5, 5-15, available at http://1.usa.gov/MpCCJ1.

95. Allison \& Tiller, supra note 49.

96. Id.

97. Id. 
media generally portrays business method patents in a negative light. ${ }^{98}$ A subsequent empirical study conducted by Professor Starling Hunter likewise concluded that business methods did not fall below an average quality metric. ${ }^{99}$

\section{InSTITUTIONAL REACTIONS TO BUSINESS METHODS ACROSS THE THREE BRANCHES OF GOVERNMENT}

Several egregious cases involving NPEs aggressively wielding broad business method patents against well-known companies triggered a wave of public scrutiny. ${ }^{100}$ Public policymakers responded as vocal and influential patent law stakeholders voiced the alarm. Policymakers operate through public institutions, which provide a forum for assembling information and bringing stakeholders together. In the patent field, there is a diverse, active, and vocal group of stakeholders continually vying to shape patent law and policy. ${ }^{101}$ A recent study conducted by the author found that 191 separate for-profit corporations filed amicus briefs in 16 recent Supreme Court patent cases. ${ }^{102}$ A subsequent study by Professor Colleen Chien found that, in the past 20 years of patent amicus brief advocacy, more than 1,500 amici, representing thousands of organizations, companies, and individuals, have signed onto briefs in hundreds of patent law cases. ${ }^{103}$

Policymakers' institutional reactions to interest groups are evident in all three branches of government, which respond to varying degrees to interest group advocacy. ${ }^{104}$ From a positive political theory perspective, policymakers often do not initiate regulatory oversight unless interest groups first voice the alarm. ${ }^{105}$ The alarm and call for regulatory reform

98. See sources cited supra note 94 .

99. Starling D. Hunter III, Have Business Method Patents Gotten a Bum Rap? Some Empirical Evidence, 6 J. INFO. TECH THEORY \& APPLICATION 1, 4 (2004).

100. Id.

101. Orozco \& Conley, supra note 6, at 109.

102. Id.

103. Colleen V. Chien, Patent Amicus Briefs: What the Courts' Friends Can Teach Us about the Patent System, 1 U.C. IRVINE L. REV. 395 (2011).

104. Stuart Minor Benjamin \& Arti K. Rai, Who's Afraid of the APA? What the Patent System Can Learn from Administrative Law, 95 GEO. L.J. 269, 310-1 1 (2007).

105. The "fire alarm" model of regulatory change was first described by Mathew D. McCubbins \& Thomas Schwartz in Congressional Oversight Overlooked: Police Patrols Versus Fire Alarms, 28 AM. J. POL. ScI. 165, 165-79 (1984). The "fire alarm" model has been widely discussed in political science and legal scholarship examining regulatory and administrative behavior from a positive political theory perspective. See Mathew D. McCubbins et al., Structure and Process, Politics and Policy: Administrative Arrangements and the Political Control of Agencies, 75 VA. L. REV. 431, 434-35 (1989) (mentioning various congressional oversight techniques); Sidney A. Shapiro, Political Oversight and the Deterioration of Regulatory Policy, 46 ADMIN. L. REv. 1, 7 (1994) 
is then delegated to administrative agencies, such as the PTO, under what has been called the "fire-alarm model" of regulatory oversight." 106 If policymakers respond to interest group pressure, it is expected that administrative agencies will then respond to policymakers' concerns under the principal-agent theory of administrative decision-making. ${ }^{107}$ From this perspective, elected policymakers exercise considerable discretion over administrative rulemaking and policy given their ability to enact legislation, approve staffing, and engage in general oversight and control of an agency's funding through appropriations. ${ }^{108}$ As with various other agencies, Congress is generally the ultimate decisionmaker with respect to the PTO's budgets and appointments. Congress also "conducts oversight and investigations, and engages in casework on behalf of constituents."109 Scholars recognize that congressional hearings are effective instruments for achieving social goals and extracting concessions from industry. ${ }^{110}$

As will be discussed next, the judicial, legislative, and executive branches all coordinated a spirited public debate concerning business method patents. This heightened interest in business methods was manifested through judicial patent levers, hearings, proposed legislation, roundtable discussions, and public policy papers. The argument advanced here is that these different institutional mechanisms signaled a clear and unified expression of how seriously this diverse group of policymakers considered the alarm raised by constituents with respect to business methods.

(two chief ways Congress might supervise agencies: "police patrol" and "fire alarm" oversight).

106. McCubbins and Schwartz, supra note 105 .

107. Kerwin, supra note 11 , at 220-21.

108. When the business method administrative patent levers were implemented, the PTO lacked fee-setting authority, which, according to Professor Arti Rai, is an important power for an agency with operations that are entirely fee-based. See Rai, supra note 15, at 2056. Under current law, the PTO may keep its fees; however, Congressional appropriators must make this decision annually; see also 35 U.S.C. $\S 42(\mathrm{e})$ (2006). Recently, Section 10 of The America Invents Act granted the PTO fee setting authority.

109. Kerwin, supra note 11, at 29.

110. See, e.g., Nathaniel Grow, In Defense of Baseball's Antitrust Exemption, 49 AM. Bus. L.J. 211 (2012) (discussing how Congress has used the threat of removing major leagues baseball's antitrust exemption during congressional hearings to extract procompetitive results in that industry); JAMES EDWARD MILLER, THE BASEBALl BusINESS: Pursuing Pennants and Profits In Baltimore 6 (1990) (stating that Congressional hearings were held in the 1950s and 1960s to pressure "baseball to expand, to improve the situation of the minor league, or to [provide] increased television or radio coverage"). Another scholar examines the role of Congressional hearings to conduct oversight of foreign affairs in the executive branch as an example of positive political theory. See David Zaring, CFIUS as a Congressional Notification Service, 83 S. CAL. L. REv. 81 (2009). 


\section{A. Reactions from the Judiciary}

In several instances, the Judiciary echoed the alarm concerning the harmful effects of business methods. This alarm, in turn, influenced the PTO's administrative decision-making since the agency's rules are guided by the Supreme Court's statutory interpretations of the Patent Act. In particular, two recent Supreme Court cases shed light on how the Court reacted to business methods.

In $e$ Bay v. MercExchange, the NPE MercExchange sought to obtain a permanent injunction against eBay after successfully asserting a business method patent against the online retailer. ${ }^{111}$ The legal doctrine at issue in that case applied to patents in general because the decision reframed the test for awarding a permanent injunction in patent cases as one involving the traditional factor test for equitable relief. ${ }^{112}$ Justice Kennedy, however, wrote a concurring opinion with three other justices that singled out business methods as deserving additional scrutiny under the factor test. Justice Kennedy wrote:

An industry has developed in which firms use patents not as a basis for producing and selling goods but, instead, primarily for obtaining licensing fees. For these firms, an injunction, and the potentially serious sanctions arising from its violation, can be employed as a bargaining tool to charge exorbitant fees to companies that seek to buy licenses to practice the patent. When the patented invention is but a small component of the product the companies seek to produce and the threat of an injunction is employed simply for undue leverage in negotiations, legal damages may well be sufficient to compensate for the infringement and an injunction may not serve the public interest. In addition injunctive relief may have different consequences for the burgeoning number of patents over business methods, which were not of much economic and legal significance in earlier times. The potential vagueness and suspect validity of some of these patents may affect the calculus under the four-factor test. ${ }^{113}$

111. eBay Inc. v. MercExchange, 547 U.S. 388, 390 (2006).

112. Id. at 391 ("According to well-established principles of equity, a plaintiff seeking a permanent injunction must satisfy a four-factor test before a court may grant such relief. A plaintiff must demonstrate: (1) that it has suffered an irreparable injury; (2) that remedies available at law, such as monetary damages, are inadequate to compensate for that injury; (3) that, considering the balance of hardships between the plaintiff and defendant, a remedy in equity is warranted; and (4) that the public interest would not be disserved by a permanent injunction."); see also David Orozco \& James G. Conley, The "Longer Walk" After eBay v. MercExchange, 42 LES NOUVELLES 426, 429 (2007) (discussing the eBay v. MercExchange decision and its impact on licensors).

113. eBay Inc. v. MercExchange, 547 U.S. at 396 (emphasis added) (citations omitted). Positive political science theorists argue that the Judiciary makes determinations that are less likely to be overturned by the Legislature or unenforced by 
In the more recent Bilski v. Kappos case, the Court held that business methods are patentable subject matter. ${ }^{114}$ Justice Kennedy, once again speaking for the Court, reiterated the particular dangers raised by business methods:

At the same time, some business method patents raise special problems in terms of vagueness and suspect validity. The Information Age empowers people with new capacities to perform statistical analyses and mathematical calculations with a speed and sophistication that enable the design of protocols for more efficient performance of a vast number of business tasks. If a high enough bar is not set when considering patent applications of this sort, patent examiners and courts could be flooded with claims that would put a chill on creative endeavor and dynamic change. ${ }^{115}$

In Bilski, the Supreme Court rejected the CAFC's exclusive application of the machine-or-transformation test for business methods. ${ }^{116}$ The CAFC may have decided to raise the bar on business methods and depart from State Street in the Bilski case due to the significant criticism targeting business methods. As suggested by scholars, the social importance of an issue before appellate courts is measured by the amicus briefs filed in response to the case. ${ }^{117}$ Amicus briefs are seldom filed in appellate court cases. In the Bilski case, however, 39 briefs were filed before the CAFC, indicating that the case and the overall issue of business method patentability raised an extraordinary alarm among parties interested in patent law. ${ }^{118}$

\section{B. Reactions from the Legislature}

The business method warning perhaps rang loudest during the early years of the Internet when Amazon.com threatened to assert its "one-

the Executive. Although it cannot be stated with certainty, it is plausible that the Supreme Court's treatment of business methods follows this paradigm. See McNollgast, Conditions for Judicial Independence, 15 J. CONTEMP. LEGAL ISSUES 105, 124 (2006); McNollgast, Politics and the Courts: A Positive Theory of Judicial Doctrine and the Rule of Law, 68 S. CAL. L. REv. 1631, 1633 (1995).

114. Bilski v. Kappos, 130 S. Ct. 3218, 3228 (2010).

115. Id. at 3218 (internal citations omitted).

116. Id. at 3227. The CAFC's machine-or-transformation test was developed to determine whether a business method was tied to a machine or transformed data in a technical manner. Under this test, if the business method failed to meet the machine-ortransformation criteria, the business method would be deemed abstract and not patentable.

117. See Gregory A. Caldeira \& John R. Wright, Organized Interests and Agenda Setting in the U.S. Supreme Court, 82 AM. POL. SCI. REV. $1109,1109-22$ (1988); Orozco \& Conley, supra note 6 .

118. The author counted the amicus briefs using Lexis-Nexis. 
click" e-commerce method patent against online competitors. ${ }^{119}$ When this occurred, companies quickly realized the danger of business methods and began to sound the alarm to elected representatives. ${ }^{120}$ In 2009 , the Chief Executive Officer of Micron Technology warned legislators of the dangers related to NPEs asserting business methods during a legislative hearing on patent reform. The corporate executive stated:

It is increasingly routine to read of a single lawsuit in which an NPE/plaintiff has sued a dozen or more companies. For example, a plaintiff recently sued twenty separate financial institutions in a single action, claiming that its patent on a point of sale debiting system was infringed by the institutions' various payment services. Another case named 22 companies as defendants, asserting that each was infringing the plaintiff's broadly-worded patents relating to security scanning. Another NPE just filed a lawsuit accusing forty companies of violating two patents relating to computer-assisted sales. $^{121}$

The House of Representatives and the Senate routinely hold patent hearings related to patent law and administration. Since 1995, the House has held 38 separate patent-related hearings. ${ }^{122}$ The Senate, in turn, has

119. For example, in response to Amazon asserting its one-click business method patent, the Free Software Foundation (FSF) advocated a complete boycott of Amazon's services. See Boycott Amazon!, FREE SOFTWARE FouND., available at: http://bit.ly/auUuQx (last visited Aug. 14, 2012); see also Korn, supra note 41, at 1372.

120. Legislators hold hearings to demonstrate responsiveness to constituents' demands. Hearings also send a signal to institutional actors in the other branches of government. As a federal matter, issues related to patents are initially heard in the House Subcommittee on Intellectual Property, Competition, and the Internet and in the Senate Committee on the Judiciary.

121. Patent Reform in the 111th Congress: Legislation and Recent Court Decisions: Hearing Before the S. Comm. on the Judiciary, 111 th Cong. (2009) (statement of Steven Appleton, Chairman and CEO, Micron Tech., Inc.); see also Patent Quality Improvement: Hearing Before the H. Subcomm. on Courts, the Internet, \& Intellectual Prop., 108th Cong. (2003) (statement of David M. Simon, Chief Patent Counsel for Intel Corp.) ("Several problems contribute to making this 'patent troll' business model a simple and effective source of illegitimate profit irrespective of the quality of the patent. For example, if the troll can claim that the patent covers $\$ 5$ billion in annual revenue, that troll will ask for a royalty fee of a few percentage points of revenue; e.g., $\$ 150$ million per year. While that may seem to be an absurd amount to pay to someone who bought a patent out of bankruptcy for less than one hundred thousand dollars, the troll will threaten the legitimate business with a permanent injunction at the end of the patent case, threatening the halt of the sale of a critical product or closing down a production facility. Even if the chance of the troll winning is low, the troll's costs are modest, normally a few million dollars at most. In contrast, the legitimate business the troll targeted faces potential financial ruin if it can no longer sell a key product. Intel recently faced such a troll who wanted $\$ 8$ billion and a permanent injunction after purchasing the patent for $\$ 50,000 . ")$.

122. This statistic is based on the author's own research involving the various hearing transcripts. 
held eight separate patent-related hearings since that date. ${ }^{123}$ These hearings, at times, deal with topics specific to certain industries, such as biotechnology, general oversight on PTO appropriations and administration, and legislative proposals for patent reform.

The first recorded discussion of business method patents in the Legislature occurred on March 25, 1999, when the House held an oversight hearing on patent reform. ${ }^{124}$ Since then, transcripts reflect a mention of business methods 20 times in House hearings and twice in Senate hearings. These statistics represent a mention of business methods in 53 percent of the House hearings and 25 percent of Senate hearings related to patents. This level of attention devoted to one particular technology area is extraordinary. Oftentimes, during these hearings, the issue of business methods was raised as a factor related to the decline of patent quality indicators due to the difficulties patent examiners face when searching business method-related prior art. ${ }^{125}$ As stated in one hearing:

The quality of a patent is synonymous with the value of that patent, and patent quality is dependent on the extent to which an invention has been certified to be useful, novel and nonobvious when compared to the existing state of the art. A poor quality patent, on the other hand, is typically invalid and may have far-reaching and negative ramifications for the individuals involved, as well as for the economy at large. ${ }^{126}$

One measure used to assess the elusive concept of patent quality is the rate at which patent applications are re-examined or declared invalid in court. ${ }^{127}$ Scant evidence, however, was introduced in the legislative hearings, and empirical data specifically related to business methods was lacking. ${ }^{128}$ In 2001, a patent hearing in the House was devoted

123. Id.

124. Id.

125. See, e.g., Patent Quality Improvement: Hearing Before the H. Subcomm. on Courts, the Internet, \& Intellectual Prop., 108th Cong. (2003) (statement of John Thomas) [hereinafter Patent Quality Hearing] ("Persistent accounts suggest that patent quality remains at less than optimal levels.").

126. Patent Quality Improvement: Hearing Before the H. Subcomm. on Courts, the Internet, \& Intellectual Prop., 108th Cong. (2003) (statement of Rep. Howard Berman).

127. See PTO WHITE PAPER, supra note 50; Allison \& Hunter, supra note 36, at 73236 (discussing that patent quality is an inherently elusive concept and that problems with patent quality exist in all fields of technology).

128. See, e.g., Patent Quality Hearing, supra note 125. In this hearing, dealing specifically with patent quality, the statements about patent quality were conclusory in nature, and no empirical evidence aside from anecdotal accounts was introduced to indicate that business methods were below average quality. Id. These statements support Allison \& Tiller's position, supra note 49 , regarding a behavioral bias against business methods. In addition, the National Academy of Sciences stated: 
specifically to the issue of business methods. ${ }^{129}$ During this hearing, the PTO's Business Method Patent Initiative was discussed, with various witnesses providing their thoughts on the efficacy of the initiative. ${ }^{130}$ Other topics discussed included the policy implications of treating business methods as a separate patent category, and the support for and against business method-specific legislation. ${ }^{131}$

Hand in hand with the various hearings, which send signals to patent law stakeholders, the Legislature introduced bills as a response to the alarms. The first instance of legislation targeting business methods was The American Inventors Protection Act of 1999 (the "Protection Act"). ${ }^{132}$ This legislation modified the Patent Act to provide a first user defense against business methods. The Protection Act provides a defense to a charge of infringement of a patent on a "method of doing or conducting business" if the accused infringer, in good faith, reduced the method to practice at least one year before the patent was filed, and commercialized the method in the United States any time before the patent filing date. ${ }^{133}$ The Protection Act was passed in response to the alarm raised by what was perceived as the low quality of business method patents. ${ }^{134}$

[T] he claim that quality has deteriorated in a broad and systematic way has not been empirically tested. Three seemingly direct measures of quality are (1) the ratio of invalid to valid patent determinations in infringement lawsuits, (2) the error rate in PTO quality assurance reviews of allowed patent applications, and (3) the rate of claim cancellation or amendment or outright patent revocation in re-examination proceedings in the PTO. These indicators show mixed results.

Stephen A. Merrill et al., Nat'l ACad. Of SCis., A Patent System for the 21 st CENTURY 48 (2004) [hereinafter NAS REPORT]; see also Jeffrey R. Kuester \& Lawrence E. Thompson, Risks Associated with Restricting Business Method and E-Commerce Patents, 17 GA. ST. U. L. REv. 657, 679 (2001) (discussing that no economic analysis has been provided by business method patent critics to justify their position that, on the whole, these patents are costly to society).

129. Business Method Patents: Hearing Before the H. Subcomm.. on Courts, the Internet, \& Intellectual Prop., 107th Cong. (2001).

130. The PTO's Business Method Patent Initiative is discussed further below in relation to the administrative patent levers. See infra Part V.

131. The various legislative hearings discussing patent issues and business methods are on file with the author.

132. American Inventors Protection Act of 1999, Pub. L. No. 106-113, §§ 4001, 4502(a), 113 Stat. 1501, 1501A-561.

133. 35 U.S.C. $\$ 273(2000)$.

134. See, e.g., Patent Reform and the Patent and Trademark Office Reauthorization for Fiscal Year 2000: Hearing Before the H. Subcomm. on Courts, the Internet, \& Intellectual Prop., 106th Cong. 229 (1999) (statement by The National Association of Manufacturers (NAM)). For example, NAM stated:

A prior user defense will be even more useful in new subject areas such as biotechnology, software, and business methods than in more traditional subjects such as chemistry. Applications in young fields strain the expertise and resources of the PTO, inasmuch as much more of the pertinent prior art is 
Proposals to target business methods were included in another bill called The Business Methods Improvement Act of 2001 (the "Improvement Act"). ${ }^{135}$ The Improvement Act, though never passed, was introduced to address concerns in the Legislature that patents for abstract ideas and weak patents were hindering innovation. ${ }^{136}$ The Improvement Act would have changed the obviousness standards related to business methods and would require the following:

A business method invention shall be presumed obvious under this section if the only significant difference between the combined teachings of the prior art and the claimed invention is that the claimed invention is appropriate for use with a computer technology, unless ... (A) the application of the computer technology is novel; or (B) the computer technology is novel and not the subject of another patent or patent application. ... ${ }^{137}$

The intended effect of this language would be to prevent applicants from receiving business method patents for innovations that were novel simply because they were implemented with the aid of a computer. Another provision in the Improvement Act would have created an opportunity for the public to submit evidence of prior art while the patent application was under review and to provide for an opposition procedure under a lower standard of proof.

In 2011, Congress enacted significant patent reform with the passage of The America Invents Act (the "Invents Act"). ${ }^{138}$ The Invents Act exempts from patentability any tax strategy patents, which are a subset of business methods. ${ }^{139}$ In addition, Section 18 of the Invents Act allows a defendant to a patent suit involving financial business methods

found outside of previous, readily searched patents. Accordingly, it is simply easier for a search to miss relevant prior art, with the result of a questionable patent being issued. ... The sharp rise in business method applications since the State Street Bank decision demonstrates that some parties had shied away from the expense of seeking a patent owing to the uncertainty that the subject matter would even be found acceptable. Such parties should not be penalized now, with loss of the right to practice their own technology, for a valid business Id. judgment then.

135. H.R. 1332, 107th Cong. (2001).

136. See Korn, supra note 41, at 1376.

137. H.R. 1332, 107th Cong. § 4(d)(1)(A)-(B) (2001).

138. S. 23,112 th Cong. $\$ 14$ (2011) ("For purposes of evaluating an invention under section 102 or 103 of title 35, United States Code, any strategy for reducing, avoiding, or deferring tax liability, whether known or unknown at the time of the invention or application for patent, shall be deemed insufficient to differentiate a claimed invention from the prior art."); see also Chumney, Baumer \& Sawyers, supra note 28.

139. See Chumney, Baumer \& Sawyers, supra note 28. 
to challenge the validity of the patent at the PTO. ${ }^{140}$ This type of postissuance patent challenge is singular since it would apply retroactively to all previously issued business method patents, in addition to those that might be issued in the future. This provision would also lack the existing time limitations usually reserved for post-issuance oppositions. Section 18 has been criticized as an appeasement to the financial services industry since it applies only to financial business methods. Section 18 states:

For purposes of this section, the term 'covered business method patent' means a patent that claims a method or corresponding apparatus for performing data processing operations utilized in the practice, administration, or management of a financial product or service, except that the term shall not include patents for technological inventions. ${ }^{141}$

\section{Reactions from the Executive Branch}

Several agencies within the Executive branch of government raised the alarm concerning business methods. The most obvious executive agency to look to for alarm signals is the PTO itself. In March 2000, in response to the alarm over business methods, the PTO launched a Business Method Patent Initiative that included industry outreach and quality programs. ${ }^{142}$ The industry outreach included a series of roundtable meetings with stakeholders on issues related to business methods. At the first roundtable, a topic for consideration was whether computer-implemented business method patents encouraged or curbed growth in innovation. ${ }^{143}$ Since March 2000, the PTO has held yearly business method patent roundtables to discuss topics related to business methods.

140. See Leahy-Smith America Invents Act, Pub. L. No. 112-29, § 18, 125 Stat. 284 (2011) (to be codified at 35 U.S.C. $\S 2(b)(2)(G)$ ).

141. H.R. 1249, 112th Cong. \$ 18 (2011).

142. Notice of Roundtable on Computer-Implemented Business Method Patent Issues, 65 Fed. Reg. 38,811, 38,811-13 (June 22, 2000) ("The industry outreach programs are intended to encompass the establishment of a customer partnership with industry, the convening of a roundtable forum, and an effort to obtain industry feedback on prior art issues. The quality programs encompass steps to enhance the technical training of examiners, revise the examination guidelines and examples, and expand current prior art search activities. This includes a review of mandatory search areas, the establishment of a new second-level review of all allowed applications in Class 705, and an expansion of the sampling size for quality review along with the introduction of a new in-process review of Office actions to focus on field of search and patentability issues involving novelty and nonobviousness.").

143. See id. 
The U.S. Federal Reserve Banks of Chicago and Atlanta have also conducted roundtables on business methods. ${ }^{144}$ For example, in April 2003, the Federal Reserve Bank of Atlanta invited academics and practitioners to discuss the effects of business method patents on the financial services industry. The conference announcement posed the following questions for consideration:

What are the implications of these developments for the evolution and structure of the financial services industry? How will they affect business strategy? Will the granting of business methods patents stifle product and service innovation or will it promote a vibrant industry? How has the U.S. Patent Office approached the questions of whether certain business methods are or are not eligible for patent protection? $^{145}$

In addition to hearings and roundtables, several departments within the Executive branch issued policy papers that highlighted the dangers of business methods. For example, in July 2009, the PTO prepared a Business Methods White Paper (the "PTO White Paper") that mentions some of the unique challenges related to examining business methods. The PTO White Paper states:

Patent examining in Class 705 is filled with challenges. This class contains diverse business topics (e.g. insurance and inventory systems). Prior art references can be found in many diverse sources (e.g. an Internet web site, a sales brochure, or a 120-year-old textbook). There is poor tabulation of all the available references for a particular topic (e.g. not all the insurance prior art is found in one location). ${ }^{146}$

The Federal Trade Commission (FTC) is another prominent administrative agency that has been critical of business methods. In

144. See, e.g., Richard Heckinger ET AL., Fed. Reserve Bank of Chi., INTEllectual Property, AND FINANCIAL MARKETS COMPETITION: A DisCusSion OF Selected Public Policy Issues 6 (2007), available at http://bit.ly/MccQGE.

145. See 2003 Financial Markets Conference Announcement: Business Method Patents and Financial Services, FED. RESERVE BANK OF ATLANTA, http://bit.ly/RngdNl (last visited Aug. 14, 2012); see also America Invents Act: Hearing on H.R. 1249 Before the H. Subcomm. on Intellectual Prop., Competition, \& the Internet, 112th Cong. 3 (2011) (statement of Steve Bartlett for the Financial Services Roundtable) ("Given the importance of the financial services sector to the nation's economy and infrastructure, it is important that the patent system work for this industry. Currently, it does not. Instead, the confluence of sector interoperability, frequent forum shopping, and a lack of quality prior art-particularly in the area of business method patents--has conspired to leave financial firms, from the smallest community bank, local credit union or insurance agent, to the largest global companies, mired in meritless litigation over patents of dubious quality.").

146. PTO WHITE PAPER, supra note 50. 
October 2003, the FTC published a report that has been cited by the Supreme Court ${ }^{147}$ and in legislative hearings. ${ }^{148}$ In the report, To Promote Innovation: The Proper Balance of Competition and Patent Law and Policy, the FTC praised the PTO's use of additional levels of review for business methods, reiterated the view that business methods had traditionally been exempted from patentability, ${ }^{149}$ and discussed the difficulty locating adequate business method prior art. ${ }^{150}$

In 2004, The National Academy of Sciences (NAS) published a comprehensive analysis of the patent system called $A$ Patent System for the 21st Century. In that report, the NAS stated that it is "concerned about trends in the application of the obviousness standard to business method and genetic sequence inventions." "51 They also responded to Allison and Tiller's ${ }^{152}$ work suggesting that indicators of business method quality failed to show any cause for alarm. In response to that work, the NAS questioned whether

[t]he body of nonpatented prior art in the area of business methods is so large or diverse that examiners are still missing a good share of it?

Does the examination process overlook some business methods that are in common use but not documented in written sources? ${ }^{153}$

To provide context, given the numerous alarms raised in response to business methods, Table 1 provides a chronology of major events related to business methods. As will be discussed next, this coordinated and vigorous response generated a set of tangible administrative outcomes at the PTO.

Table 1. Timeline of Significant Business Method Events

\begin{tabular}{|l|l|}
\hline Year & Event \\
\hline 1998 & $\begin{array}{l}\text { The CAFC's State Street decision recognizes business methods as } \\
\text { patentable subject matter }\end{array}$ \\
\hline 1999 & $\begin{array}{l}\text { Amazon.com asserts its "one-click" business method patent against } \\
\text { competitors }\end{array}$ \\
\hline
\end{tabular}

147. See Microsoft v. i4i Ltd. P'ship, 131 S. Ct. 2238 (2011); KeRWIN, supra note 11; eBay v. MercExchange, L.L.C., 547 U.S. 388 (2006).

148. See Comm. Print Regarding Patent Quality Improvement: Hearing Before the H. Subcomm. on Intellectual Prop., Competition, \& the Internet, 109th Cong. (2005) (statement of Richard J. Lutton, Jr., Chief Patent Counsel for Apple, Inc.).

149. See Fed. Trade Comm'n, To Promote Innovation: The Proper Balance of COMPETITION AND PATENT LAW AND POLICY (2003), available at http://1.usa.gov/ixpdVn.

150. See id. at 46.

151. NAS REPORT, supra note 128 , at 62.

152. Allison \& Tiller, supra note 49.

153. NAS REPORT, supra note 128 , at 50. 


\begin{tabular}{|c|c|}
\hline 1999 & $\begin{array}{l}\text { The first time the term "business method patent" was discussed in } \\
\text { legislative hearings in the House }\end{array}$ \\
\hline 1999 & $\begin{array}{l}\text { The American Inventors Protection Act is enacted and provides a } \\
\text { prior use defense against business methods }\end{array}$ \\
\hline 2000 & $\begin{array}{l}\text { The PTO implements the Business Method Patent Initiative to } \\
\text { address quality issues concerning business method patent } \\
\text { applications }\end{array}$ \\
\hline 2001 & $\begin{array}{l}\text { The House holds a hearing specifically to address business method } \\
\text { patents }\end{array}$ \\
\hline 2001 & $\begin{array}{l}\text { The Business Method Patent Improvement Act is introduced to } \\
\text { raise the obviousness standard for business methods }\end{array}$ \\
\hline 2003 & $\begin{array}{l}\text { The Federal Reserve Bank of Atlanta holds a 3-day research } \\
\text { conference on business methods and their impact on the financial } \\
\text { services industry }\end{array}$ \\
\hline 2003 & $\begin{array}{l}\text { The Federal Trade Commission prepares a report, "To Promote } \\
\text { Innovation: The Proper Balance of Competition and Patent Law and } \\
\text { Policy," that highlights problems related to business methods }\end{array}$ \\
\hline 2004 & $\begin{array}{l}\text { The National Academy of Science publishes a comprehensive } \\
\text { analysis of the patent system called "A Patent System for the } 21 \mathrm{st} \\
\text { Century" expressing concern over business methods }\end{array}$ \\
\hline 2006 & $\begin{array}{l}\text { The Supreme Court describes some business methods as being } \\
\text { particularly vague and of suspect validity in eBay v. MercExchange }\end{array}$ \\
\hline 2007 & The PTO institutes the Peer-to-Patent Project \\
\hline 2008 & $\begin{array}{l}\text { The CAFC decides In Re Bilski and applies the "machine or } \\
\text { transformation test" to evaluate business methods under a higher } \\
\text { standard than State Street }\end{array}$ \\
\hline 2010 & $\begin{array}{l}\text { The Supreme Court states that business methods raise special } \\
\text { problems in Bilski v. Kappos }\end{array}$ \\
\hline 2011 & $\begin{array}{l}\text { The America Invents Act is a comprehensive patent reform bill that } \\
\text { makes tax strategies not patentable and allows defendants in cases } \\
\text { involving financial business methods to challenge issued patents at } \\
\text { the PTO }\end{array}$ \\
\hline
\end{tabular}

V. THE PTO’S RESPONSE TO BUSINESS METHOD FIRE ALARMS: ADMINISTRATIVE PATENT LEVERS

The PTO invested significant resources ${ }^{154}$ and promptly implemented rules to address the concern exhibited about business methods. In particular, the PTO implemented rules to address the issue of patent quality related to this technology class, given the concerns

154. See Allison \& Hunter, supra note 36 , at 785 . 
voiced regarding unduly broad business method patents. On March 29, 2000 , the PTO announced the Business Method Patent Initiative, which included industry outreach and quality programs. ${ }^{155}$ The industry outreach programs established "a customer partnership with industry, the convening of a roundtable forum, and an effort to obtain industry feedback on prior art issues." 156 As stated by the PTO, the quality programs provide steps to "enhance the technical training of examiners, revise the examination guidelines and examples, and expand current prior art search activities." 157

Five business method-specific rules will be discussed next. A remarkable aspect of these rules is that, as administrative patent levers, they target a specific item of patent reform applied within the context of a particular technology. ${ }^{158}$ This exercise of administrative policy is singular since the Patent Act, as originally contemplated, is silent regarding any sui generis treatment of technology classes. ${ }^{159}$ Under the general goal of enhancing patent quality, the following administrative rules were implemented to deal with challenges unique to business methods. The goal of improving patent quality in light of industryspecific challenges provides the PTO with the legal legitimacy to enact technology-specific regulations that attain the objective of issuing patents that meet statutory criteria. ${ }^{160}$

Given that prominent fire alarms related to business methods were triggered at the highest levels of government, the PTO's response was to identify the means for regulating this category of patents to improve patent quality during the examination process. The first four administrative patent levers addressing business method quality originated in the Business Method Patent Initiative as either: (1) rules pertaining to examination procedures, or (2) partnerships with external parties to strengthen the level of prior art assessments during examination. The last rule involving peer-to-patent was not part of the Business Method Patent Initiative but falls under the second category.

155. Press Release, PTO, USPTO to Hold Roundtable Meeting on Computer Implemented Business Method Patent Initiatives (July 29, 2000) available at http://1.usa.gov/RB3928.

156. Id.

157. Id.

158. Burk \& Lemley, supra note 7 (arguing for specific judicial changes to patent doctrine to deal with diverse patent law preferences and context-dependent policy outcomes).

159. Other areas where the PTO has created administrative patent levers include software, biotechnology, and green technologies. A detailed account of these policyoriented rules is beyond the scope of this article. For a detailed assessment of PTO rulemaking in these areas, see Orozco, supra note 18.

160. Patent quality primarily refers to issuing patents that meet the statutory criteria of novelty and non-obviousness. 


\section{A. Examination Procedures}

\section{New Expert Examiner Category}

In the PTO White Paper, the PTO described a new category of experts specifically retained to help examiners evaluate business method patent applications. These additional experts are called Business Practice Specialists. ${ }^{161}$ According to the PTO, these specialists

will be pursued from industry to serve as a resource for examiners on common or well-known industry practices, terminology, scope and meaning, and industry standards in four basic areas: banking/finance, general e-commerce, insurance, and Internet infrastructure. ${ }^{162}$

These experts will assist with training efforts to help examiners stay abreast of the latest developments in the various business method-related fields of art. The only other technology field that uses this category of experts is technology unit 2100-Computer Architecture and Software Management. ${ }^{163}$

\section{Mandatory Field Searching}

Traditionally, examiners assign a primary technology classification code to a patent application, and the code assigns the patent to a PTO technology unit for subsequent examination purposes. ${ }^{164}$ Secondary technology classification numbers are also assigned to indicate the prior art databases that will be searched during examination. Examiners evaluating business methods are required under the revised procedure, however, to search a predetermined and exhaustive list of patent and non-patent literature to assess business method prior art. ${ }^{165}$ Under these rules, "examiners perform a mandatory search for all applications in Class 705 that includes databases with U.S. patents, foreign patent documents, and non-patent literature (NPL)." ${ }^{.166}$ No other technology classes require mandatory searches of specific databases. ${ }^{167}$

161. PTO WHITE PAPER, supra note 50, at 21.

162. Id.

163. See Biotechnology and Organic Chemistry Management Roster, PTO, http://1.usa.gov/RB5oTf (last visited Aug. 4, 2012).

164. See PTO, Overview of the U.S. Patent Classification System 16 (2011), available at http://1.usa.gov/Qs2AL1.

165. PTO WHITE PAPER, supra note 50, at 14-20.

166. Business method patent references must be searched in databases such as: ABI/INFORM, Business \& Industry, Business Week, Business Wire, Computer Database, Conference Papers Index, Dissertation Abstracts Online, Globalbase, Inside Conferences, INSPEC, Internet \& Personal Computing Abstracts, The McGraw-Hill Companies Publications Online, Microcomputer Software Guide Online, New Product Announcements/Plus (NPA/Plus), Newsletter Database, Newspapers, Financial Times 


\section{3. "Second Pair of Eyes" Review}

In March 2000, the PTO established the mandatory "second pair of eyes" review for business method patents in Class 705. ${ }^{168}$ As described by the PTO, "second pair of eyes" review

is a 'universal' review of all allowances in Class 705 with each allowance taking about one hour. The purpose of this review is for the reviewer to quickly flag issues that need further consideration by the examiner and/or the examiner's supervisor. In fiscal year 2001, the 'second pair of eyes' review in Class 705 resulted in a reduction of the Class 705 reopening percentage by the Office of Patent Quality Review (OPQR) to zero percent. For FY 2002, only one 705 application was reopened as a result of review by the OPQR. ${ }^{169}$

All allowed business method patents are, therefore, subjected to an additional review, and a larger than normal sample of these allowances are then screened through the OPQR. ${ }^{170}$ The "second pair of eyes" review is a novel procedure that had never been implemented in any other technology class prior to its application to business methods. ${ }^{171}$

\section{B. Partnerships with External Parties}

1. Coordination with External Parties to Improve Search Capabilities

Other unique rules implemented by the PTO to address business method fire alarms include outreach efforts with external parties. One rule seeks input from external parties to augment the PTO's non-patent literature (NPL) prior art databases. The following are two separate statements made by two high-ranking PTO officials during Congressional testimony:

Indeed, our examiners have access to more prior art than ever before.... While these improvements are encouraging, we continue working with private parties to expand examiners' access to nonpatent literature. For example, last year we held hearings in San Francisco and here in Washington on this very matter. I am pleased

Abstracts, New York Times Abstracts, San Jose Mercury News, Wall Street Journal Abstracts PR Newswire, and PROMT.

167. A comprehensive search failed to yield any similar uses of mandatory searches in other technology units.

168. Patent Quality Improvement: Expansion of the Second-Pair-of-Eyes Review, PTO, http://1.usa.gov/OQZfEj (last updated Sept. 20, 2007).

169. Id.

170. Allison \& Hunter, supra note 36 , at 737.

171. Id. at 734 . 
that, as a result of these efforts, organizations such as the Securities Industry Association have come forward to help our office expand access to state of the art information in their areas. ${ }^{172}$

As part of our on-going Business Methods Patent Initiative, since August 2000 we have tripled the number of customer partnerships (from 10 to 31 ) with the patent community and the software, Internet and electronic commerce industries. As part of these partnerships, we are soliciting input from our customers on additional sources of prior art that our examiners can utilize. ${ }^{173}$

This level of coordination with industry to improve the access to prior art is in some ways singular to the business methods technology class and is only rivaled by the software and gene patent fields. ${ }^{174}$

\section{Peer-to-Patent}

The peer-to-patent project was an effort undertaken by the PTO in June 2007 to open up the application review process to external reviewers who may submit relevant prior art and statements to a patent examiner. ${ }^{175}$ Originally, this limited pilot project was undertaken to examine software patents, but shortly after its announcement, business methods were added to its scope. ${ }^{176}$ As stated by the PTO:

Recently a group of academic and business professionals have proposed a collaborative, online process in which members of the public pool together their knowledge and locate potential prior art. This pilot will test whether such collaboration can effectively locate prior art that might not otherwise be located by the Office during the typical examination process. ${ }^{177}$

The project has been conducted on a purely voluntary basis, with patent applicants choosing to opt into the peer-to-patent review process. In exchange for volunteering, the applicant receives an expedited review

172. U.S. Patent and Trademark Office: Hearing Before the Subcomm. on Courts, the Internet \& Intellectual Prop., 106th Cong. (2000) (statement of Hon. Todd Q. Dickinson).

173. U.S. Patent and Trademark Office: Operations and Fiscal Year 2003 Budget, Hearing Before the Subcomm. on Courts, the Internet, \& Intellectual Prop., 107th Cong. (2002) (statement of James E. Rogan).

174. See Orozco, supra note 18.

175. See Peer Review Pilot Program, PTO, http://1.usa.gov/Ml0Luh (last updated Nov. 8, 2010).

176. PTO Announcement, Extension and Expansion of Pilot Concerning Public Submission of Peer Reviewed Prior Art (July 17, 2008), available at http://1.usa.gov/5bwEu.

177. Id. 
process and, in theory, a more robust examination that yields a higher quality issued patent. ${ }^{178}$ Although the PTO participated in the project, it was conducted in collaboration with the Community Patent Review Project of the Institute for Information Law and Policy at New York Law School. ${ }^{179}$

The second anniversary report of the peer-to-patent project stated that 187 patent applications had been reviewed as of May 2009. ${ }^{180}$ The PTO deemed the initial two-year pilot program a success and agreed to continue the project. The extended period for receiving peer-to-patent submissions into accepted applications ended on either February 3, 2012, or 18 weeks after the latest date on which an application was accepted into the program, whichever occurred later. ${ }^{181}$ This new program was also expanded by including "Life Sciences, Telecommunications, and Computer Hardware, and by significantly increasing the total number of applications that may be accepted into the pilot." 182

Although it is not entirely certain that the PTO's administrative patent levers caused a drop in patent granting for business methods, there is some evidence corroborating this view. For example, the NAS report provided evidence that the granting of business methods exhibited a notable decline after the PTO implemented its Business Method Patent Initiative. ${ }^{183}$ The overall trend for business method patent grants increased but at a decreasing rate, from 1995 when 200 patents were granted, up until the end of 2000 , with nearly 1,000 of these patents granted that year. ${ }^{184}$ In 2000, the PTO also implemented its Business Method Patent Initiative and, in 2001, the grants of these patents dropped

178. See Daniel R. Bestor \& Eric Hamp, Peer to Patent: A Cure for Our Ailing Patent Examination System, 9 Nw. J. TECH. \& INTELL. Prop. 16, 17 (2010).

179. Id. The PTO, however, took effort to state its independence from the project in the following disclaimer:

The Office and the Community Patent Review Project are independent entities, and are not agents of each other. Peer-to-Patent is a non-Office website developed by the Community Patent Review Project of the Institute for Information Law and Policy at NY Law School. Peer-to-Patent is responsible for the management of the Internet based review process by the public. The Office does not set the membership or agenda, nor assume authority or control over Peer-to-Patent or the Community Patent Review Project. Neither party is authorized or empowered to act on behalf of the other with regard to any contract, warranty or representation as to any matter, and neither party will be bound by the acts or conduct of the other.

Id.

180. Ctr. for Patent InNovations, PeEr-to-Patent Second Anniversary Report 5 (2009), available at http://bit.ly/kysJc.

181. PTO Announcement, A New Pilot Program Concerning Public Submission of Peer Reviewed Prior Art, at 3 (Dec. 12, 2012), available at http://1.usa.gov/OIsQ0L.

182. Id.

183. NAS REPORT, supra note 128 , at 57.

184. Id. 
below $900{ }^{185}$ By 2003, the PTO was granting nearly 800 business method patents. ${ }^{186}$ According to the PTO, the grant rate for business method patents has markedly decreased, from 45 percent in 2001, the year after the Business Method Patent Initiative was launched, to 20 percent by mid-year 2007. ${ }^{187}$ The lower grant rate reflects that fewer patents are being granted despite a growing number of business method application filings. In 2002, the PTO received 7,400 total business method applications; by 2010 , that number had increased to 17,231 applications. ${ }^{188}$

To respond to the quality issues raised in the various alarm mechanisms, and to address the growing backlog of business method applications, the PTO increased the number of examiners to process Class 705 applications from 77 in 2001 to 197 in 2007. ${ }^{189}$ Yet, the PTO has reported that, in 2009 , the average pendency rate on the application for a business methods patent until a final disposition was reached was 46.1 months (3.8 years) ${ }^{190}$ However, this account has been challenged. One scholarly assessment of financial method patents, which are a subset of business methods, reports that total average pendency for this technology area is above 7 years. ${ }^{191}$ In the worst scenario, an anecdotal account reports that an acting Patent Commissioner stated that the pendency for business methods was ten years. ${ }^{192}$ To place this data in context, a recent 2011 account of the average pendency for all patents is 33.7 months. ${ }^{193}$

\section{ADMINISTRATIVE LAW IMPLICATIONS}

The PTO's deployment of administrative patent levers raises several important administrative law issues. One issue involves whether, upon judicial review, the CAFC would permit the current and future implementation of administrative patent levers in other technology

185. Id.

186. Id.

187. Wynn W. Coggins, Grp. Dir., PTO Tech. Ctr. 3600, Update on Business Methods for the Business Methods Partnership Meeting (June 19, 2007) (PowerPoint on file with author).

188. Class 705 Patent Application Filing and Patents Issued Data, PTO, http://.usa.gov/PvQ73Z (last updated May 5, 2011).

189. Id.

190. Andrew T. Spence, Patentable Subject Matter, INTELl. ProP. AdVISORY (Alston \& Bird L.L.P.), July 27, 2009, at 1, 5, available at http://bit.ly/MWQY3w.

191. John F. Duffy \& John A. Squires, Disclosure and Financial Patents, Revealing the Invisible Hand 5, Working Paper (2008), available at http://bit.ly/OR2hZd.

192. See, e.g., Russ Krajec, Claiming Business Method Patents: Taking Advantage of Long Pendency, BLOG (2012), http://bit.ly/MG1BTM.

193. Patent Pendency Statistics, PTO, http://1 usa.gov/N6t7MS (last updated Jan. 3, 2012). 
areas. ${ }^{194}$ This is a relevant inquiry because, in the past, the CAFC has constrained the PTO's authority to engage in rulemaking whenever it ventures into substantive ${ }^{195}$ or policy-oriented ${ }^{196}$ rulemaking.

To answer these questions, a descriptive account will assess how the CAFC would likely analyze the PTO's administrative patent levers if a business method patent applicant legally challenges them. A prescriptive solution is then advanced that suggests what might be a potentially superior solution to the existing legal framework. This prescriptive solution is justified under policy grounds due to four important reasons including: (1) the legitimate role that administrative patent levers play to regulate controversial technologies, (2) the technology neutral aspects of the Patent Act, (3) the possibility of regulatory capture at the PTO, and (4) the unintended consequences that unfairly impact some patent applicants.

\section{A. General Administrative Patent Law Framework}

Administrative rulemaking falls into three general categories of factual, legal, and policy-oriented rulemaking. ${ }^{197}$ The level of judicial review applied to administrative actions depends on whether the authority-granting statute mentions the scope of authority granted to the agency and the level of review that courts are supposed to apply. ${ }^{198}$ The courts resort to administrative law defaults when the statute is either silent or ambiguous about the nature of authority granted to the agency. In such cases, if the administrative action involves either facts or policy, the Administrative Procedure Act (APA) defines these defaults. ${ }^{199}$

Because agencies are presumed to have high degrees of expertise, findings of fact are scrutinized under Section 706 of the APA, which states that courts are to review an agency's factual determinations using a capricious, arbitrary, or abuse of discretion standard during informal proceedings, or an unsupported by substantial evidence standard during formal proceedings. ${ }^{200}$ At one point, the CAFC did not grant any deference to the PTO's factual findings. The Supreme Court reversed

194. The PTO has signaled their desire to regulate other technology areas. See Press Release, PTO, Peer Review Pilot FY2011 (last modified May 31, 2011) [hereinafter PTO Press Release], available at http://1.usa.gov/i8ZOlb.

195. See Tafas v. Doll, 559 F.3d 1345, 1352 (Fed Cir. 2009) (stating that Section 2(b) 2 of the Patent Act "does not vest the USPTO with any general substantive rulemaking power").

196. See In re Fisher, 421 F.3d 1365, 1378 (Fed. Cir. 2005) (stating that public policy concerns are more appropriately determined by the legislature).

197. Benjamin \& Rai, supra note 104, at 284.

198. Id. at 279-80.

199. Benjamin \& Rai, supra note 104, at 317-18.

200. Id. at 285. 
this position in Dickinson v. Zurko ${ }^{201}$ and required the CAFC to apply Section 706 deference to the PTO's factual findings. The CAFC has since applied, as a general matter, the unsupported by substantial evidence standard to any of the PTO's factual findings. ${ }^{202}$

Administrative rules that implicate policy are likewise scrutinized under an APA default provision-in this case Section $706(2)(\mathrm{A})^{203}-$ which mandates a hard look review. Under hard look review, courts hold that an agency is required, when implementing a regulation that has policy ramifications, to take a hard look at and consider any significant considerations against the rule's implementation. ${ }^{204}$

Administrative rulemaking that carries the force of law is scrutinized within the framework created by Supreme Court cases Chevron $^{205}$ and Mead. ${ }^{206}$ In Chevron, the Court developed the eponymous doctrine, which comprises two steps. Step one determines whether the statute is clear regarding the agency's authority to issue regulations that provide legal interpretations of the statute. If the statute is silent or vague, deference is given to the agency's interpretation as long as it is reasonable. ${ }^{207}$ The Mead case refined and narrowed this analysis by holding that, in cases where the statute did not delegate "authority to the agency generally to make rules carrying the force of law," a Skidmore level of deference applies. ${ }^{208}$ Under a Skidmore level of review, a court reviews agency action based on "the thoroughness evident in its consideration, the validity of its reasoning, its consistency with earlier and later pronouncements, and all those factors which give it power to persuade."209

\section{B. The CAFC's Framework for Assessing the PTO's Administrative Patent Levers}

In some significant aspects, the CAFC departs from applying traditional administrative law principles in its review of PTO actions. ${ }^{210}$

201. Dickinson v. Zurko, 527 U.S. 150 (1999).

202. This standard has been generally applied even though the capricious, arbitrary, or abuse of discretion standard should apply because the PTO engages in informal proceedings. See Benjamin and Rai, supra note 104, at 287-88.

203. 5 U.S.C. $\S 706(2)$ (A) (2006) ("The reviewing court shall-(2) hold unlawful and set aside agency action, findings, and conclusions found to be (A) arbitrary, capricious, an abuse of discretion, or otherwise not in accordance with law.").

204. Benjamin \& Rai, supra note 104, at 304.

205. Chevron U.S.A., Inc., v. NRDC, Inc., 467 U.S. 837 (1984).

206. United States v. Mead Corp., 533 U.S. 218 (2001).

207. Benjamin and Rai, supra note 104, at 296 (citing Chevron, 467 U.S. at 844).

208. See United States v. Mead Corp., 533 U.S. 218, 226-27, 230-31 (2001).

209. Skidmore v. Swift \& Co., 323 U.S. 134, 140 (1944).

210. Benjamin and Rai, supra note 104 , at 280. 
What follows is an attempt to predict how the CAFC would review the PTO's administrative patent levers if they were to be challenged as beyond the PTO's delegated authority. ${ }^{211}$ Taking into account recent case law, the author posits that it is possible that the CAFC would examine the PTO's administrative patent levers under two scenarios. These two scenarios depend on whether the CAFC would collapse the analysis of administrative patent levers as an issue involving factual determinations or as one of rulemaking that carries the force of law. ${ }^{212}$

\section{Analysis of PTO Rules that Reflect Factual Findings}

As scholars have noted, the CAFC fails to recognize that the PTO engages in policy-oriented decision making. ${ }^{213}$ Professors Benjamin and Rai analyze the Supreme Court case of In re Fisher ${ }^{214}$ to persuasively make this point. ${ }^{215}$ In the Fisher case, the PTO rejected claims for a gene fragment based on lack of utility ${ }^{216}$ by applying the 2001 PTO guidelines for utility patents (the "utility guidelines"). ${ }^{217}$ The utility guidelines were drafted with policy concerns in mind to address overly broad genetic information patent applications. ${ }^{218}$

The Fisher Court, however, never acknowledged the policy foundations underpinning the utility guidelines and instead chose to review the PTO's denial of the relevant claims as simply a question of fact. $^{219}$ As stated by the CAFC, "Whether an application discloses a utility for a claimed invention is a question of fact." 220 The CAFC then reviewed the PTO's denial under the unsupported by substantial

211. PTO rulemaking has been challenged in the past by patent applicants who allege that they have been denied substantive rights. See In re Bogese, 303 F.3d 1362 (Fed. Cir. 2002) (concerning a patent applicant that challenged the PTO's denial of the patent application based on the applicant's unreasonable and undue delay in prosecution); Tafas v. Doll, 559 F.3d 1345 (Fed. Cir. 2009) (challenging PTO's rules relating to patent applications involving continuations and claim numbers); In re Fisher, 421 F.3d 1365 (Fed. Cir. 2005) (challenging the PTO's utility guidelines for assessing the utility of gene-related patents).

212. See Benajmin and Rai, supra note 104 , at 305-06.

213. Id. at 306 .

214. In re Fisher, 421 F.3d 1365 (Fed. Cir. 2005).

215. See Benajmin and Rai, supra note 104, at 305-06.

216. See 35 U.S.C. $\$ 101$ (2006) (requiring that a patentable invention be "useful").

217. The 2001 utility guidelines can be seen as technology-specific and policy oriented administrative patent levers in the field of biotechnology. For a more detailed account of administrative patent levers in biotechnology, software, and green technology, see Orozco, supra note 18.

218. Professors Benjamin and Rai state that the PTO instituted the utility guidelines in response to being denied the ability to address overreaching genetic information patents under the obviousness standard. See Benjamin and Rai, supra note 104, at 307.

219. See In re Fisher, 421 F.3d at 1372.

220. Id. at 1369 . 
evidence standard discussed in In re Zurko. ${ }^{221}$ In the end, the CAFC held that the PTO had met the burden imposed by administrative law principles. Nevertheless, the CAFC reiterated that the PTO's utility guidelines were simply advisory and could "be given judicial notice to the extent they do not conflict with the statute.,222

If any of the business method administrative patent levers were challenged due to a patent application denial, it is possible that the CAFC would ignore the public policy aspects of the rules altogether. The CAFC may instead confine the issue as one involving a statutory matter, such as a rejection of the patent application on the grounds of obviousness or lack of novelty, as done in Fisher. ${ }^{223}$ Business method administrative levers are largely procedural and are used to improve examination and availability of prior art; therefore, any denial of a business method application founded on its use would likely meet the substantial evidence standard of In re Zurko as long as the issue was narrowly confined to a factual question involving prior art. This outcome would be undesirable, however, because it would sidestep the central issue of administrative patent levers being used as policy instruments that address technology-specific issues and would necessitate an altogether different standard of review.

\section{Analysis of PTO Rules Having Legal Effect}

If the CAFC categorizes the PTO's administrative patent levers as rules carrying the force of law, the CAFC would likely embark on the procedural versus substantive analysis adopted in Tafas v. Doll. ${ }^{224}$ As often stated by the CAFC, the PTO lacks substantive rulemaking authority. ${ }^{225}$ According to the CAFC, any rules that veer into substantive territory are beyond legality and the bounds of delegated authority granted to the PTO by the Patent Act under 35 U.S.C. \& 2(b)(2). In relevant part, Section 2(b)(2) states that the PTO may

221. Towards the very end of the opinion, the court addressed the policy arguments raised by the PTO and its amici. The court, in a telling manner, stated that the concerns were "public policy considerations which are more appropriately directed to Congress as the legislative branch of government, rather than this court as a judicial body responsible simply for interpreting and applying statutory law." In re Fisher, 421 F.3d at 1378.

222. Id. at 1372 (quoting EnzoBiochem v. Gen-Probe, 323 F.3d 956, 964 (Fed. Cir. 2002)).

223. See In re Fisher, 421 F.3d 1365 (Fed. Cir. 2005).

224. See Tafas v. Doll, 559 F.3d 1345 (Fed. Cir. 2009).

225. The CAFC stated that "[we] agree with the district court that $\S 2$ (b)2 'does not vest the USPTO with any general substantive rulemaking power." Id. at 1352 (quoting Tafas v. Dudas, 541 F. Supp. 2d 805, 811 (E.D. Va. 2008)). 
establish regulations, not inconsistent with law, which... (A) shall govern the conduct of proceedings in the Office;... (C) shall facilitate and expedite the processing of patent applications, particularly those which can be filed, stored, processed, searched, and retrieved electronically... (D) may govern the recognition and conduct of agents, attorneys, or other persons representing applicants or other parties before the Office. . . ${ }^{226}$

In Tafas, the CAFC did not provide a bright-line test for determining when a rule is either procedural or substantive. As scholars and the courts recognize, this is a difficult issue because rules at times combine elements of procedure and substance. ${ }^{227}$ Alternatively, as stated by Professor Arti Rai, "[S]ubstance and procedure exist on a spectrum."228 However, the CAFC did endorse an earlier test mentioned in the D.C. Circuit case of JEM Broad Co. v. FCC. ${ }^{229}$ In JEM v. FCC, an administrative rule was deemed substantive when it "changed the substantive standards" applied to applicants appearing before the administrative agency. ${ }^{230}$ But the more critical consideration in $J E M v$. $F C C$ for finding that the administrative rule in question was procedural involved whether the rule would "foreclose effective opportunity to make one's case on the merits." 231 Because the FCC rules in question in JEM v. FCC did not foreclose the opportunity to apply for FCC licenses, the D.C. Circuit Court held that the rules were procedural, as opposed to substantive. Quoting the D.C. Circuit, the CAFC in Tafas endorsed the related position that procedural patent rules arise in cases involving "agency actions that do not themselves alter the rights or interests of parties, although [they] may alter the manner in which the parties present themselves or their view points to the agency."232

In Tafas, the CAFC held that all four of the rules promulgated by the PTO and challenged by the appellees were procedural in light of this framework. Even though it was acknowledged that the four rules would affect the substantive rights of patent applicants by making it more burdensome to apply for a patent, ${ }^{233}$ the Court held:

226. 35 U.S.C. \& 2(b)(2) (2006 \& Supp. 2011).

227. See Brief for Intellectual Property, Administrative Law, and Public Health Professors as Amici Curiae Supporting Defendants, Tafas v. Dudas, 511 F. Supp. 2d 652 (E.D. Va. 2008).

228. Rai, supra note 15 , at 2056.

229. JEM Broad Co. v. FCC, 22 F.3d 320 (D.C. Cir. 1994).

230. See id. at 327.

231. Id. at 328 (quoting Lamoille Valley R.R. Co. v. ICC, 711 F.2d 295, 328 (D.C. Cir. 1983)).

232. Tafas v. Doll, 559 F.3d 1345, 1356 (Fed. Cir. 2009) (quoting JEM, 22 F.3d at $326)$.

233. Two of the rules--Rules 78 and 114-related to continuation applications and requests for continued examination and required applicants to file petitions if the 
[W]e conclude that the Final Rules challenged in this case are procedural. In essence, they govern the timing of and materials that must be submitted with patent applications. The Final Rules may "alter the manner in which the parties present ... their viewpoints" to the USPTO, but they do not, on their face, "foreclose effective opportunity" to present patent applications for examination. ${ }^{234}$

Applying this framework, a strong argument can be made that all five of the business method administrative patent levers are procedural. A straightforward case can be made that the three examination rules, ${ }^{235}$ the rule extending prior art through external partnerships, and the peerto-patent process are regulations that govern examination "proceedings in the office" with the goal of improving the availability of prior art. ${ }^{236}$ In addition, even though all of these rules might make it more burdensome for business methods applicants, none of them "foreclose effective opportunity to present the patent application for examination." 237

Under Tafas, the next step applied by the CAFC to assess the legality of the PTO's procedural rulemaking involves applying Chevron deference to the PTO's interpretation of the provisions of the Patent Act that relate to "proceedings in the Office." The key question at this point is "if the statute is silent or ambiguous with respect to the specific issue" because then "the question for the court is whether the agency's answer is based on a permissible construction of the statute.",238 In Tafas, all but one of the rules survived this level of analysis. The invalidated rule required applicants to furnish additional disclosures if they submitted more than two continuation applications. The Court found that this rule added a requirement to the Patent Act that unambiguously spelled out the specific and exclusive requirements for filing patent continuations under Section 120 of the Patent Act. ${ }^{239}$ Because the statutory provision dealing

applicant wished to pursue more than a certain amount of applications. Rules 75 and 265 require applicants who submit more than more than a certain number of claims to provide the examiner with information in an examination support document. In his dissent in the Tafas case, Judge Rader views all of these rules as impermissibly infringing on the substantive rights of the applicants, in contravention of the PTO's procedural rulemaking authority, and in opposition to language in various sections of the Patent Act.

234. Tafas v. Doll, 559 F.3d 1345, 1355 (Fed. Cir. 2009) (citing JEM Broad Co. v. FCC, 22 F.3d 320, 326 (D.C. Cir. 1994)).

235. See supra Part V (involving the new examiner category, mandatory field searching, and second pair of eyes review).

236. See 35 U.S.C. § 2(b)(2) (2006 \& Supp. 2011).

237. Tafas v. Doll, 559 F.3d 1345, 1356 (Fed. Cir. 2009).

238. Chevron U.S.A., Inc., v. NRDC, Inc., 467 U.S. 837, 842-43 (1984).

239. Section 120 states:

An application for patent for an invention disclosed in the manner provided by the first paragraph of section 112 (a) ... of this title in an application previously 
with this issue was found to be clear and unambiguous, the PTO's interpretation of the statute was not afforded Chevron deference, and the rule was declared invalid. Each business method patent lever is assessed next in relation to the Patent Act to determine if they contravene the statute or provide an unreasonable interpretation of it.

Because business method administrative patent levers relate to the examination process, 35 U.S.C. $\$ 131$ is the central statutory provision in the Patent Act concerning the examination process that would be analyzed to assess their legality. The section, titled "Examination of Application," states: "The Director shall cause an examination to be made of the application and the alleged new invention; and if on such examination it appears that the applicant is entitled to a patent under the law, the Director shall issue a patent therefore."240 Given the extremely broad and ambiguous language, it is unlikely that any of the business method administrative patent levers would be viewed as unreasonable interpretations of Section 131. Applying Chevron deference, the rules would, therefore, likely stand as permissible methods for conducting the examination under Section 131.

The rules are largely procedural in nature and meant to increase the level of patent quality by making the process more rigorous and reducing the possibility of granting patents that should never have been issued. As such, they fall squarely within the authority defined by 35 U.S.C. $\S 2(b)(2)$. The only challenge that might arise under this statutory provision involves the requirement that the PTO "shall facilitate and expedite the processing of patent applications." 241 As mentioned earlier, the patent levers are associated with longer delays involving patents in Class 705. This fact alone, however, would not likely be enough to render the levers invalid because, as pointed out in Tafas, the courts will not invalidate agency action that makes it more cumbersome to comply with regulations and that, in this case, would result in delay. ${ }^{242}$

The only rule that might conflict with additional statutory provisions in the Patent Act is the peer-to-patent rule. The PTO, however, was careful in implementing the rule so it complied with the

filed in the United States, or as provided by section 363 of this title, which is filed by an inventor or inventors named in the previously filed application shall have the same effect, as to such invention, as though filed on the date of the prior application, if filed before the patenting or abandonment of or termination of proceedings on the first application or on an application similarly entitled to the benefit of the filing date of the first application and if it contains or is amended to contain a specific reference to the earlier filed application. ...

35 U.S.C. $\S 120$ (2006 \& Supp. 2011).

240. 35 U.S.C. $\$ 131(2006)$.

241. 35 U.S.C. $\& 2$ (b)(2)(c) (2006 \& Supp. 2011).

242. Tafas v. Doll, 559 F.3d 1345, 1357 (Fed. Cir. 2009). 
existing statutory framework. First, the PTO asserts its authority to enact peer-to-patent under 35 U.S.C. $\S 2$ (b)(11). That provision provides that the PTO "may conduct programs, studies, or exchanges of items or services regarding domestic and international intellectual property law and the effectiveness of intellectual property protection domestically and throughout the world," and 15 U.S.C. $\S 1525$, which provides that the PTO "may engage in joint projects, or perform services, on matters of mutual interest, the cost of which shall be apportioned equitably." ${ }^{243}$ The PTO conducts peer-to-patent in a limited pilot capacity in conjunction with New York Law School as part of a program of study. ${ }^{244}$ The statutory authority related to "programs" and "studies" suggests a more theoretical or academic exercise than what is currently achieved via the peer-to-patent project. However, the statutory language does not explicitly restrict "programs" or "studies" in this manner and is likely to be afforded Chevron deference as a reasonable interpretation of $\S 2$ (b)(11) of the Patent Act.

Peer-to-patent also requires patent applicants participating in the program to waive 37 C.F.R. 1.99(d), which provides that a third party's prior art "submission under this section shall not include any explanation of the patents or publications, or any other information." 245 The peer-topatent program complies with provisions in the Patent Act concerning third-party objections and submissions of prior art. Section $\S 122$ (c) of the Patent Act states

The Director shall establish appropriate procedures to ensure that no protest or other form of pre-issuance opposition to the grant of a patent on an application may be initiated after publication of the application without the express written consent of the applicant.

In fact, the PTO only accepts volunteers to participate in the limited peer-to-patent pilot program, and consent is required from all volunteers

243. See 35 U.S.C. $\S 2$ (b)(11) (2006 \& Supp. 2011); 15 U.S.C. $\$ 1525$ (2006).

244. See PTO Press Release, supra note 194.

245. Id. Peer-to-patent falls within the "new governance" movement, which stresses transparency and a greater role for non-state actors in government proceedings. See Neil Gunningham, The New Collaborative Environmental Governance: The Localization of Regulation, 36 J.L. \& Soc'Y 145, 146, 150 (2009) (U.K.); David L. Markell, The Role of Spotlighting Procedures in Promoting Citizen Participation, Transparency and Accountability, 45 WAKE FOREST L. REV. 425, 429 (2010) (discussing the new governance mechanism of environmental regulation known as the North American Commission for Environmental Cooperation (CEC), which allows citizens to submit allegations of environmental law violations). Professor Markell states: "The citizen submissions process is an example of a "fire alarm" mechanism in that citizens initiate the process through the filing of a submission with the CEC Secretariat." Id. at 430. 
who participate. ${ }^{246}$ The consent form requires that the applicant allow third parties to submit prior art references that explain the basis of opposition to the application. ${ }^{247}$

\section{A Normative Solution}

This section offers a normative solution squarely recognizing that traditional administrative law principles ought to apply when courts review the PTO's actions. ${ }^{248}$ As a prescriptive matter, the CAFC should recognize that, similar to the PTO's utility guidelines, the business method administrative patent levers are policy-oriented. Because the rules are primarily procedural, the rules are not actions that carry the force of substantive law, as discussed in the previous section. Even if they were substantive, however, it is still arguable that the courts should extend the appropriate level of deference to the PTO by applying the traditional administrative review called for under Skidmore. ${ }^{24}$

Although there is no clear line between legal and policy actions, ${ }^{250}$ administrative action that responds to statutory vagueness by imposing a value judgment indicates action akin to policymaking. Scholars have also identified ways that the courts and PTO engage in policymaking when they target specific technologies in response to unique and technology-specific challenges. ${ }^{251}$ These value judgments, which also characterize business method administrative patent levers, clearly reflect PTO policymaking. Because administrative patent levers reflect policy judgments, they fall in an entirely different category of review under established administrative law doctrine.

The recommended alternative to the current administrative law quagmire $^{252}$ is for the courts ${ }^{253}$ to explicitly recognize that the PTO

246. Press Release, PTO, Pilot Concerning Public Submission of Peer Reviewed Prior Art, at 1 (2007), available at http://1.usa.gov/N7oH8n.

247. Id. at 4 .

248. Benjamin \& Rai, supra note 104, at 271-72; Jonathan S. Masur, Regulating Patents, 2010 SUP. CT. REV. 275 (2010).

249. If any of the administrative patent levers were deemed substantive, the courts should apply Skidmore deference because this deference applies as a default except when "it appears that Congress delegated authority to the agency generally to make rules carrying the force of law, and that the agency interpretation claiming deference was promulgated in the exercise of that authority." Mead Corp., 533 U.S. at 226-27.

250. Benjamin \& Rai, supra note 104, at 302.

251. Burk \& Lemley, supra note 7; Benjamin \& Rai, supra note 104, at 303.

252. Benjamin \& Rai, supra note 104, at 302 .

253. It is unclear whether the CAFC would overturn its precedent and explicitly engage in this normative shift. The Supreme Court, however, might favorably endorse this position. In the past, the Court has indicated that patent law should follow more traditional administrative law doctrine. See, e.g., Dickinson v. Zurko, 527 U.S. 150 (1999). 
engages in policymaking. Scholars have made a strong case for why the PTO should be allowed to engage in policymaking, as most other agencies do, ${ }^{254}$ because the Patent Act is relatively broad, and virtually all agencies are empowered and expected to engage in policymaking to some degree. In this respect, the PTO should not be an exception. This way, the PTO would be allowed to implement administrative patent levers to overcome policy vacuums, political gridlock, statutory ambiguity, and judicial lack of expertise and facts. The reviewing courts, however, would still fill an indispensable role as reviewers of the ultimate legality of their implementation.

A well-established framework exists for courts to review administrative policymaking. That framework is informed by the APA's gap filling Section 706(2)(a), which states that a reviewing court shall "hold unlawful and set aside agency action, findings, and conclusions found to be (A) arbitrary, capricious, an abuse of discretion, or otherwise not in accordance with law...."255 Courts have applied this section to agency policymaking by mandating a "hard look" level of review. A hard look review, as mandated by the Supreme Court, requires that "the agency must examine relevant data and articulate a satisfactory explanation for its action including a rational connection between the facts and the choice made., 256 An agency's failure to respond to alternatives or any arguments that counter its actions would be deemed "arbitrary or capricious within the meaning of Section 706(2)(A).",257

The leading Supreme Court case involving hard look review of administrative decision making is Motor Vehicle Manufacturers Association v. State Farm Mutual Automobile Insurance. ${ }^{258}$ In the State Farm case, the Court stated that a court is "not to substitute its judgment for that of an agency. Nevertheless, the agency must examine the relevant data and articulate a satisfactory explanation for its action including a 'rational connection between the facts found and the choice made." ${ }^{259}$ Additionally, the Court stated that an agency rule would be arbitrary and capricious if the agency entirely failed to consider an

254. Benjamin \& Rai, supra note 104; Masur, supra note 248.

255. 5 U.S.C. $\S 706(2)(A)(2006)$.

256. Motor Vehicle Mfrs. Ass'n v. State Farm Mut. Auto. Ins. Co., 463 U.S. 29, 43 (1983).

257. Benjamin \& Rai, supra note 104, at 304 n. 186; see also Sierra Club v. EPA, 356 F.3d 296, 305-07 (D.C. Cir. 2004).

258. Motor Vehicle Mfrs. Ass'n v. State Farm Mut. Auto. Ins. Co., 463 U.S. 29 (1983).

259. Id. at 43 (citing Burlington Truck Lines, Inc. v. United States, 371 U.S. 156, 168 (1962)). 
important aspect of the problem or offered an explanation for its decision that runs counter to the evidence before the agency. ${ }^{260}$

It is possible that none of the business method administrative patent levers would survive scrutiny under a State Farm line of inquiry. The levers would not survive scrutiny under State Farm because there is no evidence on the record to suggest that the PTO considered findings under the novel two-part test advocated in this article. The first part of the recommended test requires offering objective evidence that business methods, particularly business methods in Class 705, presented a challenge that merited special consideration. Anecdotal evidence and conclusory assertions were offered that referenced litigation or media accounts of egregious examples of special challenges involving business methods. ${ }^{261}$ Yet, the PTO offered nothing resembling objective evidence or a scientific study to justify the claim that business methods merited special treatment. $^{262}$ It is precisely this kind of evidence, however, that should justify a policy decision. The second part of the hard look review advocated here would assess whether the PTO failed to consider any evidence that ran counter to the assertion that business methods were unusually dangerous. There have been rigorous empirical studies which show that this is not the case, namely the study conducted by Professors Allison and Tiller. ${ }^{263}$ Yet, the PTO never addressed these contrary findings before implementing their business method administrative patent levers.

At this point, it should be noted that a hard look review would not unduly hamper the PTO in its decision to implement administrative patent levers. A legitimate concern is that the PTO lacks policymaking expertise to rebut objective evidence that disputes whether the levers are

260. Id. at 43 .

261. Kuester \& Thompson, supra note 128 , at 658 . Interestingly, the PTO never subjected any of the business method administrative patent levers to the informal rulemaking process, which might have triggered some of the factual counter arguments against the rules.

262. Id.; see also NAS REPORT, supra note 128 , at 48 ("The claim that quality has deteriorated in a broad and systematic way has not been empirically tested. Three seemingly direct measures of quality are (1) the ratio of invalid to valid patent determinations in infringement lawsuits, (2) the error rate in PTO quality assurance reviews of allowed patent applications, and (3) the rate of claim cancellation or amendment or outright patent revocation in re-examination proceedings in the PTO. These indicators show mixed results."). In 2010, the PTO hired a Chief Economist who is "responsible for advising the Under Secretary and the Administrator for External Affairs on the economic implications of policies and programs affecting the United States intellectual property system." USPTO Economic Research Agenda, PTO, http://1.usa.gov/exrtgc (last visited Aug. 5, 2012). The office of the PTO Chief Economist might be an important actor in future efforts to justify PTO policy actions, such as the use of administrative patent levers.

263. See Allison \& Tiller, supra note 49; Allison \& Hunter, supra note 36. 
warranted. However, this claim is unfounded, especially because the PTO has devoted resources to policymaking in the past. Most recently, the PTO even hired a Chief Economist and support staff to guide its policymaking agenda. ${ }^{264}$

From a policy perspective, administrative patent levers can be important tools for administrative decision-making in response to unique and legitimate challenges. Patent levers are sometimes required to respond to policy vacuums left open by the courts and the legislature. Certain technology areas clearly present unique challenges to the Patent Office. However, if particular challenges such as declining patent quality arise within a specific technology area, as alleged to be the case with business methods, the PTO should present at least an objective basis for these challenges to justify any technology-based and sui generis rulemaking.

The purpose of hard look judicial review under Section 706(2)(A) of the APA would be to hold the PTO objectively accountable in this respect. This accountability is important given that the PTO advanced scant empirical evidence, other than anecdotal accounts, to demonstrate that business methods are generally of below average quality. ${ }^{265}$ Apart from the sake of harmonization and applying established administrative law doctrine to the PTO's actions, vigorous judicial review of PTO policymaking is important for the following reasons: (1) the important implications for innovation and the economy (because the Patent Act is technology neutral); (2) the risk of regulatory capture; and (3) the unfair results and unintended consequences that may be generated by the use of administrative patent levers. Each of these additional considerations is discussed next.

Industry specific policy determinations are perhaps best reserved for the Legislature and Judiciary to implement. ${ }^{266}$ As imperfect as it may be to coordinate legislative adjustments to the Patent $\mathrm{Act},{ }^{267}$ the Legislature has revised the Patent Act in the past to account for industry-specific differences and objectives. For example, Congress amended the Patent Act to provide defendants in business methods cases with the first user defense. $^{268}$ Congress also amended the Patent Act to account for the

264. David Kappos, Speech to the National Bureau of Economic Research (Apr. 20, 2010), available at http://1.usa.gov/OV6mgy.

265. Id.

266. See Orozco \& Conley, supra note 6; In re Fisher, 421 F.3d 1365, 1378 (Fed. Cir. 2005).

267. Especially when the reform goals are broad. See supra notes 5-6 and accompanying text.

268. 35 U.S.C. $\S 273$ (2006 \& Supp. 2011). 
particular needs of patentees in the biotechnology ${ }^{269}$ and university research $^{270}$ industries. According to some commentators, the largely general and technology neutral aspects of the Patent Act have encouraged innovation across a broad swath of industries. ${ }^{271}$

A particularly striking example of how a broad, technology-neutral interpretation of the Patent Act may spur the creation and development of an important industry is in the context of biotechnology. In the landmark case of Diamond v. Chakrabarty, ${ }^{272}$ the Supreme Court held that living organisms can be patentable subject matter. The Court endorsed a technology-neutral policy when it famously stated that Congress intended statutory subject matter in the Patent Act to "include anything under the sun that is made by man." ${ }^{, 273}$ Some scholars argue that this technology-neutral interpretation of the Patent Act spurred the creation of an innovative and vibrant biotechnology industry comprised of small entrepreneurial companies. ${ }^{274}$

Evidence suggests that administrative patent levers may be subject to political influence and pressure, particularly from powerful interest groups. ${ }^{275}$ As a matter of national technology and innovation policy, this pressure begs the question of whether administrative patent reform should be primarily guided by technology-neutral principles or by industry-specific concerns. The risk in the latter approach is that interest groups with political power may have an advantage raising the requisite fire alarms. ${ }^{276}$ For example, a particular industry group might initiate congressional hearings that scrutinize a competing technological

269. The Biotechnology Process and Patent Protection Act of 1995, Pub. L. No. 10441,109 Stat. 351 (codified at 35 U.S.C. $\$ 103(2000)$ ).

270. The Bayh-Dole Act of 1980, Pub. L. No. 96-517, 94 Stat. 3018 (codified as amended at 35 U.S.C. §§ 200-12 (1994)).

271. See Richard A. Epstein et al., The FTC, IP, SSOs: Government Hold-up Replacing Private Coordination, Competition, 8 J. COMPET. L. \& ECON. 1 (2012); cf. Robert M. Hunt, Patentability, Industry Structure, and Innovation (Fed. Reserve Bank of Phila. Working Paper No. 01-13/R (2004)) (arguing that a technology-neutral obviousness standard in patent law encourages innovation in some sectors but not in others).

272. Diamond v. Chakrabarty, 447 U.S. 303, 309-18 (1980) (holding that living organisms can be patentable).

273. Id.

274. Stephen H. Haber et al,, On the Importance to Economic Success of Property Rights on Finance and Innovation, 26 WASH. U. J.L. \& POL'Y 215, 223 (stating that the U.S. biotechnology industry is not rivaled in many other jurisdictions that do not provide patent protection for living organisms).

275. Section 18 of the America Invents Act provides evidence of regulatory capture of the patent system by the financial services industry.

276. See F. Scott Kieff, The Case for Preferring Patent Validity Litigation Over Second Window Review and Gold-Plated Patents: When One Size Doesn't Fit All, How Could Two do the Trick?, 157 U. PENN. L. REv. 1937, 1949 (2009) (discussing how larger firms can tie up patents by using administrative challenges). 
industry. Unless the opposing industry has effective lobbying resources, it might suffer negative repercussions manifested as administrative patent levers. Under a public choice theory of politics, regulators are prone to capture by well-funded industry groups. Direct evidence of this effect can be witnessed through the addition of Section 18 to the America Invents Act. This section has been widely criticized as a legislative carve-out that exclusively benefits the financial services industry, which now has a powerful weapon to challenge patentees asserting financial business method patents.

Permitting the PTO to engage in technology-specific policy determinations may generate unintended consequences. ${ }^{277}$ For example, Professors Allison and Hunter provide an empirical and detailed account of how patent applicants strategically attempt to game the technology classification system through creative patent drafting to avoid patent applications from being assigned to Class 705 , which would trigger the business method administrative patent levers. ${ }^{278}$ The result is a situation that unjustly rewards some applicants while hindering others without the application of sound principle justified by any sensible reading or interpretation of the Patent Act. Allison and Hunter's empirical analysis also suggests an unconscious bias within the PTO towards classifying many business methods outside of the 705 technology classification. ${ }^{279}$ The basic unfairness of this scenario is that some applications are classified within technology Class 705 and undergo administrative patent lever review, whereas other applicants proceed through a less rigorous examination process. This outcome might not satisfy the arbitrary or capricious standard under a State Farm hard look review. ${ }^{280}$

The subject of appropriate judicial review of administrative patent levers is significant. The recently enacted America Invents Act delegates policymaking authority to the PTO in a manner that would facilitate the implementation of administrative patent levers. ${ }^{281}$ For example, the Act includes a section that gives the PTO the authority to prioritize examinations for technologies that are deemed important for American competitiveness. ${ }^{282}$ The PTO has indicated that it will expand some of its administrative patent levers to other controversial and challenging technology areas such as biotechnology, semiconductors, and

277. See Kuester \& Thompson, supra note 128, at 678.

278. Allison and Hunter, supra note 36 , at 787.

279. Id. at 737.

280. Motor Vehicle Mfrs. Ass'n v. State Farm Mut. Auto. Ins. Co., 463 U.S. 29 (1983).

281. See, e.g., Leahy-Smith America Invents Act, Pub. L. No. 112-29, § 26, 125 Stat. 284 (2011).

282. Id; see Cahoy, supra note 16 , at 22. 
information technology. ${ }^{283}$ Similar issues involving regulatory capture, strategic gaming effects, and unintended consequences may be observed in these important and emergent technologies.

\section{CONCLUSION}

This article describes how the PTO implemented administrative patent levers related to business methods. These administrative patent levers represent a coordinated policy at the PTO to target a particular technology class with the goal of improving patent quality during the examination phase. This article describes how policymakers in all three branches of government reacted strongly to the dangers posed by business methods patents. The significant institutional attention, preceded by constituent alarm, led to a series of norms and rules that the PTO implemented to manage the quality of business method patent examination practices. This behavior is explained under the "fire-alarm" theory of regulatory change and positive political theory, whereby an administrative agency responds to external institutional pressures and actors. This article also highlights the important and visible role of institutional stakeholders that provide expertise to help guide PTO rulemaking.

This article also describes and predicts how the CAFC would review the PTO's administrative patent levers. Ultimately, this approach is undesirable because it does not recognize that the PTO actively engages in policymaking. A normative solution is offered whereby the reviewing courts apply a hard look review under Section 706(2)(A) of the APA. This standard would require the PTO to offer objective evidence that the administrative patent levers are warranted. The standard would also require that the PTO address any valid arguments or evidence against the implementation of these policy-oriented and technology-specific rules.

283. See PTO Press Release, supra note 194. 
